\title{
Formation of anthropogenic secondary organic aerosol (SOA) and its influence on biogenic SOA properties
}

\author{
E. U. Emanuelsson ${ }^{1}$, M. Hallquist ${ }^{1}$, K. Kristensen ${ }^{2}$, M. Glasius ${ }^{2}$, B. Bohn ${ }^{3}$, H. Fuchs ${ }^{3}$, B. Kammer ${ }^{3}$, \\ A. Kiendler-Scharr ${ }^{3}$, S. Nehr ${ }^{3}$, F. Rubach ${ }^{3}$, R. Tillmann ${ }^{3}$, A. Wahner ${ }^{3}$, H.-C. Wu ${ }^{3}$, and Th. F. Mentel ${ }^{3}$ \\ ${ }^{1}$ Department of Chemistry and Molecular Biology, University of Gothenburg, 41296 Göteborg, Sweden \\ ${ }^{2}$ Department of Chemistry, Aarhus University, 8000 Aarhus, Denmark \\ ${ }^{3}$ Institut für Energie- und Klimaforschung: Troposphäre (IEK-8), Forschungszentrum Jülich, 52428 Jülich, Germany
}

Correspondence to: T. F. Mentel (t.mentel@fz-juelich.de)

Received: 11 July 2012 - Published in Atmos. Chem. Phys. Discuss.: 14 August 2012

Revised: 25 January 2013 - Accepted: 8 February 2013 - Published: 11 March 2013

\begin{abstract}
Secondary organic aerosol (SOA) formation from mixed anthropogenic and biogenic precursors has been studied exposing reaction mixtures to natural sunlight in the SAPHIR chamber in Jülich, Germany. In this study aromatic compounds served as examples of anthropogenic volatile organic compound (VOC) and a mixture of $\alpha$-pinene and limonene as an example for biogenic VOC. Several experiments with exclusively aromatic precursors were performed to establish a relationship between yield and organic aerosol mass loading for the atmospheric relevant range of aerosol loads of 0.01 to $10 \mu \mathrm{g} \mathrm{m}^{-3}$. The yields $(0.5$ to $9 \%)$ were comparable to previous data and further used for the detailed evaluation of the mixed biogenic and anthropogenic experiments. For the mixed experiments a number of different oxidation schemes were addressed. The reactivity, the sequence of addition, and the amount of the precursors influenced the SOA properties. Monoterpene oxidation products, including carboxylic acids and dimer esters were identified in the aged aerosol at levels comparable to ambient air. $\mathrm{OH}$ radicals were measured by Laser Induced Fluorescence, which allowed for establishing relations of aerosol properties and composition to the experimental $\mathrm{OH}$ dose. Furthermore, the $\mathrm{OH}$ measurements in combination with the derived yields for aromatic SOA enabled application of a simplified model to calculate the chemical turnover of the aromatic precursor and corresponding anthropogenic contribution to the mixed aerosol. The estimated anthropogenic contributions were ranging from small $(\approx 8 \%)$ up to significant fraction $(>50 \%)$ providing a suitable range to study the effect of aerosol composition on the aerosol volatility (volume frac-
\end{abstract}

tion remaining (VFR) at $343 \mathrm{~K}: 0.86-0.94)$. The aromatic aerosol had higher oxygen to carbon ratio $\mathrm{O} / \mathrm{C}$ and was less volatile than the biogenic fraction. However, in order to produce significant amount of aromatic SOA the reaction mixtures needed a higher $\mathrm{OH}$ dose that also increased $\mathrm{O} / \mathrm{C}$ and provided a less volatile aerosol. The SOA yields, O/C, and $f_{44}$ (the mass fraction of $\mathrm{CO}_{2}^{+}$ions in the mass spectra which can be considered as a measure of carboxylic groups) in the mixed photo-chemical experiments could be described as linear combinations of the corresponding properties of the pure systems. For VFR there was in addition an enhancement effect, making the mixed aerosol significantly less volatile than what could be predicted from the pure systems. A strong positive correlation was found between changes in volatility and $\mathrm{O} / \mathrm{C}$ with the exception during dark hours where the SOA volatility decreased while $\mathrm{O} / \mathrm{C}$ did not change significantly. Thus, this change in volatility under dark conditions as well as the anthropogenic enhancement is due to chemical or morphological changes not affecting $\mathrm{O} / \mathrm{C}$.

\section{Introduction}

Formation of atmospheric secondary organic aerosol (SOA) from gas-phase precursors has received considerable attention during the last decade (Hallquist et al., 2009; Jimenez et al., 2009; de Gouw and Jimenez, 2009; Kroll and Seinfeld, 2008). Secondary organic aerosol components impact the Earth climate by supporting the formation of new particles, which increases the number density, and by condensation 
onto pre-existing particles, which increases both mass and size. Moreover, SOA formation and transformation by atmospheric processes influence the physicochemical properties of atmospheric aerosols. Depending on location, time and specific source regions, SOA can be produced from both anthropogenic and biogenic volatile organic compounds (VOC). Globally the production of biogenic SOA (BSOA) dominates over the anthropogenic (ASOA) with estimated fluxes of 88 and $10 \mathrm{TgC}$ per year, respectively (Hallquist et al., 2009). As discussed by Hallquist et al. (2009) there are large uncertainties but all estimates indicate the production of BSOA to be significantly larger than ASOA (Spracklen et al., 2011; Kanakidou et al., 2005; Heald et al., 2010; Goldstein and Galbally, 2007). Locally and regionally however, the ASOA can supersede the BSOA (e.g. Fushimi et al., 2011; Steinbrecher et al., 2000; Aiken et al., 2009). The SOA formation mechanisms are complex and even though we nowadays have a detailed chemical knowledge on the degradation of most VOC, a large part of the SOA formation and ageing is still unclear as well as understanding multi-component systems. There are several field observations where SOA has been attributed to originate from both biogenic and anthropogenic sources and it seems that anthropogenic activities enhance BSOA abundance (e.g. Aiken et al., 2009; Carlton et al., 2010; de Gouw et al., 2005, 2008; Hu et al., 2008; Shantz et al., 2004; Spracklen et al., 2011; Szidat et al., 2006, 2009).

Several studies have recently stressed the potential of anthropogenic biogenic interactions to be of importance for SOA (Spracklen et al., 2011; Hoyle et al., 2011; Glasius et al., 2011; Galloway et al., 2011; Kautzman et al., 2010). There are several potential ways of interactions, both directly by gas-aerosol chemistry and physics, and indirectly by anthropogenic influence on biogenic source strengths. In the context of the present study the chemistry of VOC from anthropogenic (AVOC) and biogenic (BVOC) compounds will be covered. This has also been the main focus of the recent laboratory study of Hildebrandt et al. (2011) and is partly covered in a number of other studies during the last years (Jaoui et al., 2008; Lambe et al., 2011; Hildebrandt et al., 2011; Derwent et al., 2010). Hildebrandt et al. found that ABSOA derived from mixtures of AVOC and BVOC can be treated as ideal mixtures. The yields can be parameterised applying the assumption of a common organic phase for partitioning. In the atmosphere there are a number of interesting issues regarding SOA formation from mixed air masses where typical anthropogenic precursors behave differently compared to biogenic precursors. Typical anthropogenic SOA precursors (AVOC) are aromatic hydrocarbons whereas typical biogenic precursors (BVOC) are terpenoids. As shown in Table 1 benzene, toluene, and p-xylene (as examples of AVOC) react slower with $\mathrm{OH}$ radicals than the unsaturated monoterpenes $\alpha$-pinene and limonene (as examples of BVOC). Moreover, monoterpenes can also be oxidized by ozone and $\mathrm{NO}_{3}$ enabling SOA production also during dark conditions. In order to elucidate this further, chamber studies were conducted here to mimic a few selected scenarios where aromatic precursors and a mixture of $\alpha$-pinene and limonene were oxidised and aged both together and separately.

To evaluate the ASOA contribution in the mixed systems there was a need for aerosol yield from pure aromatic photo-oxidation experiments at low $\mathrm{NO}_{\mathrm{x}}$. There have been a number of studies on this topic, (e.g. Healy et al., 2009; Hurley et al., 2001; Izumi and Fukuyama, 1990; $\mathrm{Ng}$ et al., 2007; Sato et al., 2007; Song et al., 2007; Takekawa et al., 2003) as discussed in the recent study of Hildebrandt et al. (2009). In their study, they reported new yields from experiments done at $\mathrm{NO}_{\mathrm{x}}$ mixing ratios $<5 \mathrm{ppb}$ (toluene/ $\mathrm{NO}_{\mathrm{x}}>250 \mathrm{ppbC} \mathrm{ppb}^{-1}$ ) using artificial sunlight. Within the current work, we conducted an extensive set of aromatic photo-oxidation experiments using natural sunlight to primarily match our experiential conditions, and secondary to compare to the findings of Hildebrandt et al. (2009). In addition to characterisation of SOA composition by aerosol mass spectrometry, filter samples were analysed to achieve insight into the chemical speciation of SOA.

\section{Experimental}

The oxidation of the VOC precursors and the following SOA formation took place in the outdoor atmosphere simulation chamber SAPHIR located on the campus of Forschungszentrum Jülich. SAPHIR is a double-wall Teflon chamber of cylindrical shape of a volume of $270 \mathrm{~m}^{3}$ and has previously been described (Rohrer et al., 2005; Bohn et al., 2005). SAPHIR is operated with synthetic air (Linde Lipur, purity $99.9999 \%$ ) and kept under a slight overpressure of about $50 \mathrm{~Pa}$. Characterization of gas phase and SOA particles were performed with a number of instruments (see below). A continuous flow of synthetic air of $7-9 \mathrm{~m}^{3} \mathrm{~h}^{-1}$ maintained the chamber overpressure and compensated for the sampling by the various instruments. This flow causes dilution of the reaction mixture with clean air. The synthetic air is also used to permanently flush the space between the inner and the outer Teflon wall. This and the overpressure of the chamber serve to prevent intrusion of contaminants into the chamber. The chamber is protected by a louvre system, which is either opened to simulate daylight conditions, exposing the reaction mixtures in the chamber to natural sun light or closed to simulate processes in the dark. A fan ensured mixing of trace gases within minutes, but reduced aerosol lifetime to about $6 \mathrm{~h}$.

In this work 17 yield experiments listed in Table 1 were performed with individual aromatic precursors (benzene, toluene, p-xylene, mesitylene, hexamethylbenzene or p-cymene (biogenic)) producing the ASOA at low $\mathrm{NO}_{\mathrm{x}}$ $(\approx 1 \mathrm{ppb})$ and high $\mathrm{NO}_{\mathrm{x}}(\approx 10 \mathrm{ppb})$ conditions. ASOA yields were determined from these experiments. In the ASOA studies we opened the roof of the chamber and exposed it to sun 
Table 1. SOA mass yields of aromatic hydrocarbons (HC) included in this study. OH rate coefficients $k_{\mathrm{OH}}$ from the NIST Kinetic Data Base. HC concentrations: initial, total loss, and the loss by chemical reaction. $\mathrm{NO}_{\mathrm{x}}$ : h and 1 refer to $10 \mathrm{ppb}$ and $1 \mathrm{ppb}$, respectively. $C_{\mathrm{OA}}$ provides the organic aerosol mass concentration at the end of the experiment, corrected for flush out, wall deposition, and background aerosol. For comparison mass yields are given for the BVOC (MT-mix of $\alpha$-pinene and limonene) and for the mixed BVOC/AVOC systems. The error for the BSOA and ABSOA systems due to the evaluation procedure is about $10 \%$. The values type set in italic for the mixed systems refer to the BVOC contributions. The $\mathrm{OH}$ reaction rate coefficients of the BVOC are $k_{\alpha-\text { pinene }}+\mathrm{OH}=5.3 \times 10^{-11} \mathrm{~cm}^{3} \mathrm{~s}^{-1}$ and $k_{\text {limonene }+\mathrm{OH}}=1.6 \times 10^{-10} \mathrm{~cm}^{3} \mathrm{~s}^{-1}$ in addition the $\mathrm{BVOC}$ react with $\mathrm{O}_{3}$ with rate coefficents of $k_{\alpha-\text { pinene }}+\mathrm{O}_{3}=8.7 \times 10^{-17} \mathrm{~cm}^{3} \mathrm{~s}^{-1}$ and $k_{\text {limonene }+\mathrm{O}_{3}}=2.13 \times 10^{-16} \mathrm{~cm}^{3} \mathrm{~s}^{-1}$.

\begin{tabular}{|c|c|c|c|c|c|c|c|c|}
\hline Exp & $\mathrm{HC}$ & $\begin{array}{l}k_{\mathrm{OH}} \\
\left(\mathrm{cm}^{3} \mathrm{~s}^{-1}\right)\end{array}$ & $\begin{array}{l}\mathrm{HC}_{\text {initial }} \\
\left(\mu \mathrm{g} \mathrm{m}^{-3}\right)\end{array}$ & $\begin{array}{l}\mathrm{HC}_{\text {lost }} \\
\left(\mu \mathrm{g} \mathrm{m}^{-3}\right)\end{array}$ & $\begin{array}{l}\mathrm{HC}_{\text {reacted }} \\
\left(\mu \mathrm{g} \mathrm{m}^{-3}\right)\end{array}$ & $\mathrm{NO}_{\mathrm{x}}$ & $\begin{array}{l}C_{\mathrm{OA}}^{1} \\
\left(\mu \mathrm{g} \mathrm{m}^{-3}\right)\end{array}$ & Yield \\
\hline$(8 / 6)$ & benzene & $1.2 \times 10^{-12}$ & 722 & 163 & 45 & $\mathrm{~h}$ & 1.4 & 0.031 \\
\hline$(7 / 6)$ & benzene & $1.2 \times 10^{-12}$ & 718 & 165 & 73 & 1 & 5.9 & 0.082 \\
\hline$(1 / 8)$ & benzene & $1.2 \times 10^{-12}$ & 795 & 255 & 75 & 1 & 0.03 & 0.0005 \\
\hline$(4 / 8)$ & toluene & $5.6 \times 10^{-12}$ & 330 & 157 & 89 & 1 & 0.18 & 0.0020 \\
\hline$(11 / 6)$ & toluene & $5.6 \times 10^{-12}$ & 203 & 72 & 48 & 1 & 1.9 & 0.039 \\
\hline$(16 / 6)$ & p-xylene & $1.4 \times 10^{-11}$ & 70 & 63 & 58 & $\mathrm{~h}$ & 2.5 & 0.042 \\
\hline$(14 / 6)$ & p-xylene & $1.4 \times 10^{-11}$ & 74 & 40 & 32 & 1 & 0.60 & 0.018 \\
\hline$(16 / 8)$ & p-xylene ${ }^{2}$ & $1.4 \times 10^{-113}$ & 196 & 44 & 27 & 1 & 0.02 & 0.0007 \\
\hline$(21 / 7)$ & p-cymene & $1.51 \times 10^{-11}$ & 93 & 62 & 56 & $\mathrm{~h}^{4}$ & 2.5 & 0.045 \\
\hline$(22 / 7)$ & p-cymene & $1.51 \times 10^{-11}$ & 97 & 69 & 59 & $\mathrm{~h}$ & 5.4 & 0.091 \\
\hline$(25 / 7)$ & p-cymene & $1.51 \times 10^{-11}$ & 92 & 51 & 38 & 1 & 0.78 & 0.021 \\
\hline$(21 / 6)$ & mesitylene & $5.67 \times 10^{-11}$ & 14 & 14 & 14 & $\mathrm{~h}$ & 0.30 & 0.021 \\
\hline$(17 / 6)$ & mesitylene & $5.67 \times 10^{-11}$ & 15 & 15 & 15 & 1 & 0.40 & 0.027 \\
\hline$(10 / 8)$ & mesitylene & $5.67 \times 10^{-11}$ & 25 & 25 & 24 & 1 & 0.01 & 0.0004 \\
\hline$(27 / 7)$ & $\mathrm{HMB}^{5}$ & $1 \times 10^{-106}$ & 263 & 198 & 180 & 1 & 0.02 & 0.0001 \\
\hline$(29 / 7)$ & HMB & $1 \times 10^{-106}$ & 240 & 190 & 168 & 1 & 0.02 & 0.0001 \\
\hline$(10 / 6)$ & MT-mix ${ }^{7}$ & see header & 287 & 229 & 221 & 1 & 55 & 0.25 \\
\hline$(10 / 6)$ & MT-mix \& toluene & see header & $287 \& 221$ & $270 \& 38$ & $258 \& 9$ & 1 & 65 & 0.24 \\
\hline$(18 / 6)$ & $\alpha$-pinene & see header & 223 & 221 & 207 & 1 & 66 & 0.32 \\
\hline$(11-12 / 6)$ & toluene\& MT-mix & see header & $214 \& 217$ & $145 \& 178$ & $54 \& 109$ & 1 & 48 & 0.30 \\
\hline$(14-15 / 6)$ & xylene\& MT-mix & see header & $76 \& 222$ & $59 \& 199$ & $31 \& 148$ & 1 & 37 & 0.21 \\
\hline$(22 / 6)$ & MT-mix \& toluene-d8 & see header & $39 \& 250$ & $39 \& 90$ & $37.5 \& 40$ & 1 & 14.5 & 0.18 \\
\hline
\end{tabular}

light before AVOC addition in order to learn about the chamber induced particle formation. The background reactivity in the chamber produced particulate mass $<0.015 \mu \mathrm{g} \mathrm{m}^{-3}$ (typically $0.005 \mu \mathrm{g} \mathrm{m}^{-3}$ ) a negligible contribution in most cases. The ASOA yields only consider AVOC induced ASOA mass and the background particulate mass was treated as an offset.

An 1:1 mixture of the monoterpenes $\alpha$-pinene and limonene served as example of biogenic precursors during other experiments. Three of the ASOA experiments and four mixed experiments (ABSOA) with biogenic and anthropogenic precursors were analysed in detail and the experimental procedures for these experiments are illustrated in Fig. 1. In ABSOA 10/6, the BVOC mixture was added initially and photo-oxidised for $2.5 \mathrm{~h}$ before the AVOC (toluene) was added and the mixture was further exposed to sunlight for $3.5 \mathrm{~h}$ prior to filter sampling. In ABSOA 11-12/6 the AVOC was added first and oxidised in sunlight for $5.75 \mathrm{~h}$ before the BVOC was added in the dark and the mixture was exposed to ozone overnight. The ozone was initially about $20 \mathrm{ppb}$ and originated from the previous photochemistry. Before the filter sampling on the subsequent 2nd day the mixture was exposed to sunlight for another $4 \mathrm{~h}$. ABSOA $14-15 / 6$ is the analogue to ABSOA $11-12 / 6$ but using xylene instead of toluene as ASOA precursor. During exp. 11/6 the mixing fan failed at 13:20 h leading to reduced particles losses during filter sampling and the subsequent ABSOA part of the experiment. For the fourth ABSOA experiment (22/6) BVOC and AVOC was added simultaneously and exposed for photo-oxidation during $6.3 \mathrm{~h}$. The experiments 13/6 and 18-19/6 illustrate pure ASOA (toluene) and BSOA ( $\alpha$-pinene), respectively.

The SAPHIR chamber is equipped with a suite of instruments. For this study several gas concentrations like $\mathrm{O}_{3}$, $\mathrm{NO}$ and $\mathrm{NO}_{2}$ were monitored, as were temperature and relative humidity. The actinic flux and the according photolysis frequencies were provided from measurements with a 


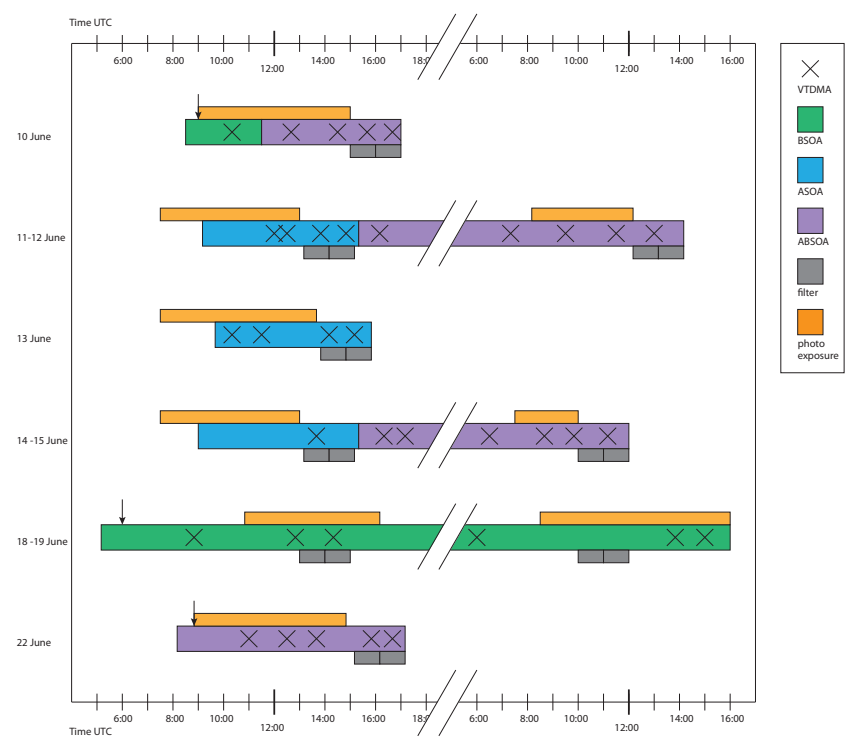

Fig. 1. An overview of the experimental procedures. Main bars indicate SOA-type; ASOA (blue), BSOA (green), and ABSOA (violet). Sunlight exposure is shown by orange bars and filter sampling by grey. Crosses indicate measurements VFR(343 K) by VTDMA. The arrows indicate when extra ozone was added to the chamber. Before experiments 11-13/6, 13/6 and 14/6 the SAPHIR chamber was exposed to sunlight before addition of organic precursor in order to determine the background reactivity.

spectral radiometer (Bohn et al., 2005). In this study we employed PTR-MS to monitor the concentrations of the VOC (Jordan et al., 2009). Particle number and number size distributions were measured by condensation particle counter (UWCPC, TSI3786) and a scanning mobility particle sizer (SMPS, TSI3081/TSI3786).

Laser induced fluorescence (LIF) was applied to measure hydroxyl radicals $(\mathrm{OH})$. The uncertainty of the $\mathrm{OH}$ measurement, which is determined by the accuracy of the calibration of the LIF instrument, is $10 \%(1 \sigma)$. The LIF instrument is described in detail by Fuchs et al. (2012). The $\mathrm{OH}$ radicals inside SAPHIR are predominantly formed by the photolysis of HONO coming off the walls, and to a minor fraction by ozone photolysis (cf. Rohrer et al., 2005). We calculated the $\mathrm{OH}$ dose in order to better compare experiments at different conditions. The $\mathrm{OH}$ dose is the integral of the $\mathrm{OH}$ concentration over time and gives the cumulated $\mathrm{OH}$ concentrations to which gases, vapours and particles were exposed at a given time of the experiment. One hour exposure to typical atmospheric $\mathrm{OH}$ concentrations of $2 \times 10^{6} \mathrm{~cm}^{-3}$ results in an $\mathrm{OH}$ dose of $7.2 \times 10^{9} \mathrm{~cm}^{-3} \mathrm{~s}$.

A High-Resolution Time-of-Flight Aerosol Mass Spectrometer (HR-ToF-AMS, Aerodyne Research Inc., DeCarlo et al., 2006) was used to measure the chemical composition of the SOA. The particles enter the instrument through an aerodynamic lens that reduces gas phase by about $10^{7}$ with respect to the particle concentration, so that only particle composition is detected, except for the main components of air; $\mathrm{N}_{2}, \mathrm{O}_{2}, \mathrm{CO}_{2}$ and $\mathrm{H}_{2} \mathrm{O}$ vapour. A tungsten oven at $600^{\circ} \mathrm{C}$ flash-vaporizes the particles under vacuum. The vapours are ionized by $70 \mathrm{eV}$ electron impact (EI), and the resulting ions are detected by means of a time-of-flight mass spectrometer applying either a high-sensitivity mode (V-mode) or a highmass resolution mode ( $\mathrm{W}$-mode). In this study we made use of the so-called MS mode, where ion signals are integrated over all particle sizes, thus the overall composition of the SOA is determined.

To characterize the degree of oxidation of the particles, two approaches were applied. The $\mathrm{O} / \mathrm{C}$ ratio was derived by elemental analysis of mass spectra obtained in the highmass resolution W-mode as described by Aiken et al. (2007, 2008). As a proxy for $\mathrm{O} / \mathrm{C}$ ratio that can be measured with higher signal to noise ratio, the ratio $f_{44}$ was also determined from high sensitivity $\mathrm{V}$-mode data. The ratio $f_{44}$ is defined as the ratio of mass concentration of $\mathrm{CO}_{2}^{+}$ions $(m / z=44 \mathrm{Th})$ to the signal of all particulate organics measured by AMS. Using all data where the organic mass loading was at least $0.5 \mu \mathrm{g} \mathrm{m}^{-3}$, we find a linear relationship between $\mathrm{O} / \mathrm{C}$ and $f_{44}$ with a slope $=3.3 \pm 0.04$, an intercept $=0.09 \pm 0.004$ and $R^{2}=0.9094$. In a similar way as $f_{44}$ characterizes the presence of carboxylic acids, $f_{43}(\mathrm{~m} / z=43$ Th divided by all organics) characterizes the presence of less oxidized, carbonyl like material.

Corrections for the (minor) influence of gaseous components preceded the calculation of the $\mathrm{O} / \mathrm{C}$ ratio, $f_{44}$ and $f_{43}$. Chamber air contains $\mathrm{CO}_{2}$ and water vapour and both gas phase species contribute to the mass spectra. The contribution of gas-phase $\mathrm{CO}_{2}$ to $\mathrm{m} / \mathrm{z}, 44$ and water vapour to $m / z \quad 18$ was inferred from measurements during periods when no particles were present. The values were subtracted to obtain the particle signals for the elemental analysis (Allan et al., 2004).

A Volatility Tandem Differential Mobility Analyser (VTDMA) set-up (Jonsson et al., 2007; Salo et al., 2011) was used to determine the thermal characteristics of the organic aerosol particles. The aerosol was sampled from the SAPHIR chamber using $6 \mathrm{~mm}$ stainless steel tubing and dried using a Nafion drier (Perma Pure PD100T-12MSS). A narrow particle diameter range was then selected using a Differential Mobility Analyser (DMA) operated in a recirculating mode. The size selected aerosol was directed through one of the eight temperature controlled paths in an oven unit under laminar flow conditions. Each heated oven consists of a $50 \mathrm{~cm}$ stainless steel tube mounted in an aluminium block with a heating element set independently from 298 to $563 \mathrm{~K} \pm 0.1 \mathrm{~K}$. To enable swift changes in evaporative temperatures the sample flow (0.3 LPM) was switched between the ovens giving a residence time in the heated part of the oven of $2.8 \mathrm{~s}$, calculated assuming plug flow. At the exit of the heated region, the evaporated gas was adsorbed by activated charcoal diffusion scrubbers to prevent re-condensation. The residual aerosol was finally 
classified using a Scanning Mobility Particle Sizer (SMPS). Because of low aerosol concentrations, the initial median particle diameter was selected to dynamically follow the aerosol size distribution and was typically set around $80 \mathrm{~nm}$. From the initial particle mode diameter $\left(D_{\mathrm{Ref}}\right)$ determined at reference temperature $(298 \mathrm{~K})$ and the final particle mode diameter $\left(D_{\mathrm{T}}\right)$ after evaporation at an elevated temperature, the Volume Fraction Remaining $(\operatorname{VFR}(\mathrm{T}))$ was defined as $\mathrm{VFR}_{\mathrm{T}}=\left(D_{\mathrm{T}} / D_{\mathrm{Ref}}\right)^{3}$ assuming spherical particles. This procedure was used to ensure that any change in particle diameter was a result of evaporation in the oven unit and to minimise artefacts such as evaporation in the sampling lines prior the VTDMA (Salo et al., 2011). Thermal characterisation was done repeatedly at several temperatures (from 298 up to $563 \mathrm{~K}$ ) or the evolution of volatility with time was monitored at a fixed temperature, e.g. VFR(343 K). An increase in VFR corresponds to a less volatile aerosol particle.

At the end of experiment sections filter samples were collected to get detailed insight into the chemical composition of the aerosol particles. The filter samples were taken using a preceding annular denuder coated with XAD-4 resin to remove gaseous species. The PTFE filters (ADVANTEC PTFE, pore size $0.2 \mu \mathrm{m}, \varnothing 47 \mathrm{~mm}$ ) were placed in stainless steel housing. Two filters were sampled after each other with a flow of $20 \mathrm{~L} \mathrm{~min}^{-1}, 1 \mathrm{~h}$ per filter, after the roof was closed at the end of the day. Filters were stored at $253 \mathrm{~K}$ prior to analysis. Extraction and analysis of the organic aerosol from the filters followed the method of Kristensen and Glasius (2011) and will only be described briefly here. Samples were extracted in acetonitrile, and the extracts were evaporated to dryness and reconstituted in $200 \mu \mathrm{L}$ of $0.1 \%$ acetic acid and $3 \%$ acetonitrile in water. All prepared samples were kept at $268 \mathrm{~K}$ until analysis. Sample extracts were analysed using a Dionex Ultimate 3000 HPLC system coupled through an electrospray (ESI) inlet to a q-TOF mass spectrometer (microTOFq, Bruker Daltonics GmbH, Bremen, Germany) operated in negative mode. The HPLC stationary phase was a Waters T3 C18 column $(2.1 \times 150 \mathrm{~mm} ; 3 \mu \mathrm{m}$ particle size $)$, while the mobile phase consisted of acetic acid $0.1 \%(\mathrm{v} / \mathrm{v})$ and acetonitrile. Pinonic acid, cis-pinic acid, terpenylic acid, diaterpenylic acid acetate (DTAA) and 3-methyl butane tricarboxylic acid (MBTCA) were quantified using authentic standards. Oxidation products from limonene along with dimer esters from $\alpha$-pinene were quantified using pinonic acid, cis-pinic acid and DTAA as surrogate standards. Recovery from spiked filters was $72-88 \%$ for all compounds except MBTCA (55\%), the uncertainty of a measurement is about $15 \%$. No correction for losses during sample handling was applied. Detection limits were $1.1-3.5 \mathrm{ng} \mathrm{m}^{-3}$ and analysis of two unexposed filters showed concentrations close to detection limits.

\section{Methods}

\subsection{Derivation of SOA yields}

Aerosol yields from single aromatic precursors were determined in experiments with production of ASOA only. The aromatic compounds have two loss terms in the SAPHIR chamber: flush out and reaction with $\mathrm{OH}$. The flush-out rate is very well defined in the chamber as the replenishment flow in a range of $7-9 \mathrm{~m}^{3} \mathrm{~h}^{-1}$ is measured directly and can in addition be deduced from inert tracers like $\mathrm{CO}_{2}$ or absolute water concentration (lifetime in a range of 28-39 h). The chemical turnover of the aromatic compounds was determined in seven minute time steps by using the drop of measured concentration of the aromatic compound, corrected for the loss by flush-out. The fraction that reacted was integrated over time to achieve the chemical turnover. For some cases we additionally calculated the chemical turnover in a different way, applying the measured $\mathrm{OH}$ and AVOC concentrations and the rate coefficient at each time step. In these cases, the sum of chemical loss and flush out deviated at maximum $15 \%$ from the observed total turnover. Particle mass was derived from particle number measurements with the SMPS system using a density of $1.4 \mathrm{~g} \mathrm{~cm}^{-3}$. Particles have additional loss terms in the chamber since they deposit and diffuse to the walls (compare Salo et al., 2011). The overall particle (typically about 5-6h) lifetime in the chamber with fan on was estimated assuming that the aerosol mass concentration $\left(C_{\mathrm{OA}}\right)$ should be constant at long times, in absence of aerosol production after correction for all loss terms. The wall loss of vapours and their potential partitioning with particles deposited on the walls was not considered. The yield is thus given by the chemical turnover of the aromatic compounds divided by the loss corrected $C_{\mathrm{OA}}$ at the end of the day, i.e. before closing the roof. The error in the yield calculation according to this approach is estimated to $\pm 20 \%$.

In the same way, the yields for the BSOA and ABSOA systems were calculated for comparison. Overall the chemical turnover and aerosol production was more distinct for the BSOA and ABSOA systems compared to the pure ASOA systems. The uncertainty due to the loss corrections are about $\pm 10 \%$ in these yield calculations.

\subsection{Classification by anthropogenic fraction}

The experiments were performed in different order of addition of AVOC and BVOC and under different reaction conditions. In order to classify the SOA according to the anthropogenic contribution, we estimated the ASOA fraction in two ways, by using the $f_{44}$ from AMS measurement and by simple conceptual model calculations. Both methods have their limitations but the results support each other.

For pure ASOA the $f_{44}\left(f_{44 \mathrm{ASOA}}\right)$ is on average 0.2 in experiment $13 / 6$ with the largest ASOA mass achieved and the best quality data. The signal $f_{44}$ does not vary much 
(0.195-0.209) over a time period of $7.5 \mathrm{~h}$ and a final $\mathrm{OH}$ dose of $8.5 \times 10^{10} \mathrm{~cm}^{-3} \mathrm{~s}$. Inspection of the BSOA during the first $2.5 \mathrm{~h}$ of experiment 10/6 with the $1: 1$ mixture of $\alpha$-pinene and limonene revealed, that this fresh BSOA had $f_{44 \text { BSOA }} \approx 0.08$ after a short induction period. The $f_{44 \text { BSOA }}$ then increased with $\mathrm{OH}$ dose, and we parameterized this increase based on and the experiment $18 / 6$ with $\alpha$-pinene by a source function of the type

$f_{44 \mathrm{BSOA}}=0.11-0.04 \times \operatorname{EXP}\left(4.5 \times 10^{-12} \times \mathrm{OH}\right.$-dose $)$

Applying this parameterization we predict $f_{44 \mathrm{BSOA}} \approx 0.1$ for pure BSOA at the end of experiments 10/6 and 22/6. Assuming linear mixing the ASOA fraction (afrac) can be estimated from the actual $f_{44}\left(f_{44 \mathrm{ACT}}\right)$ :

$\operatorname{afrac}=\frac{f_{44 \mathrm{ACT}}-f_{44 \mathrm{BSOA}}}{f_{44 \mathrm{ASOA}}-f_{44 \mathrm{BSOA}}}$

With this approach we estimated the anthropogenic fraction in the ABSOA aerosols at the end of the experiments, i.e. for the periods of filter samples, in order to compare to the model predictions described in the following. In case of experiment 22/6 we applied Eqs. (1) and (2) to calculate ASOA fractions during the course of the experiment. (These are compared to the model results in Fig. 3d.)

In a second approach we estimated the anthropogenic fraction in the mixed anthropogenic/biogenic ABSOA systems by a simplified chemical/partitioning model. The model inputs were the gas-phase concentrations of $\mathrm{OH}$, of the aromatic precursor and the particle mass as observed. We calculated the sum of all products $\left(P_{\text {sum }}\right)$ formed by the reactions of the aromatics with $\mathrm{OH}$ :

$\mathrm{AVOC}+\mathrm{OH} \rightarrow P_{\text {sum }}$

By using the measured particle mass and the yield function derived from pure ASOA experiments we calculated at each seven minutes time interval the fraction of $P_{\text {sum }}$ which supposedly is residing in the particulate phase $\left(\mathrm{PP}_{\text {sum }}\right)$ and in the gas phase $\left(\mathrm{GP}_{\text {sum }}\right)$. This information was used to calculate loss terms for $\mathrm{GP}_{\text {sum }}$ by flush out (replenishment flow as measured) and for $\mathrm{PP}_{\text {sum }}$ by flush out and particle loss (about lifetime $6 \mathrm{~h}$ ). The model thus delivers the amount of particulate aromatic products $\mathrm{PP}_{\text {sum }}$ and its fractional contribution to the total mixed aerosol. This procedure assumes instantaneous partitioning and the estimated values will be most representative at those times when the chemistry is evolved sufficiently and when the estimated macroscopic yield describes the partitioning of all oxidation products, i.e. at the end of the experiments we are aiming at. The model further assumes that aromatic oxidation products mix into a BSOA matrix as in a pure aromatic SOA. This assumption is supported by observations of Hildebrandt et al. (2011).

This procedure may overestimate the actual loss of $P_{\text {sum }}$, if the dynamically derived $\mathrm{PP}_{\text {sum }}$ is over-predicted due to slow partitioning, but it will still be a valuable tool to compare the anthropogenic contribution to the ABSOA in the mixed systems. The model estimate was tested against experimental results in two cases. The method overestimates the ASOA in the $11 / 6$ (toluene) and the $14 / 6$ (xylene) experiments by factors of 1.4 and 1.5, respectively, which we regard as a good agreement considering the simplicity of the approach. We nevertheless corrected all anthropogenic fractions derived by the model calculations by a factor of 1.4 .

In the last column of Table 3 we show the anthropogenic contributions calculated by the model divided by the correction factor of 1.4. There and in Fig. 3d we compare the estimate of the ASOA fraction utilizing $f_{44}$ from AMS measurements as described above. ASOA fractions in the ABSOA aerosols predicted by the model were used for detailed analysis of the thermal characterization with VTDMA at the end of the experiments, i.e. for the periods of filter samples.

\section{Result and discussion}

\subsection{SOA yields}

Table 1 provides calculated SOA yields for aromatic VOC, monoterpenes and the mixed experiments. Figure 2 shows the derived yields of aromatic VOC as a function of organic aerosol mass $\left(C_{\mathrm{OA}}\right)$ for the 17 experiments with aromatic precursor. The yields are increasing with the organic aerosol load $C_{\mathrm{OA}}$ as expected from Raoul's law (Pankow, 1994). A Hill function was fitted to the yields from all aromatic experiments resulting in the following expression

yield $=\frac{0.39}{1+\left(\frac{29.7}{C_{\mathrm{OA}}}\right)^{0.79}}$

The parameter base $=7.4 \times 10^{-4}$ (yield for $C_{\mathrm{OA}} \rightarrow 0$ in the Hill function) was set to 0 and the value of 0.39 in the enumerator predicts the maximum yield at infinite $C_{\mathrm{OA}}$ to be expected from the aromatic compounds.

The data are within the errors in agreement with a recent study using artificial sunlight for $\mathrm{OH}$ production (Hildebrandt et al., 2009), however at the low end site. Hildebrandt et al. (2009) corrected their yields for vapour deposition to the chamber walls or to particles deposited at the walls. The difference could thus be due to neglection of such wall effects in our case. Assuming the corrections applied by Hildebrandt et al. were correct the results indicate that wall effects in SAPHIR affect SOA yields to less than $33 \%$. For the model calculations of the anthropogenic contributions in the mixed experiments we adopted the Hill function with the parameters derived above, as it phenomenologically will present our observation better than the Hildebrandt results (Hildebrandt et al., 2009, 2011). The principal statements derived are not affected by this choice.

For BSOA we derive two yields. The yield for the BSOA in experiment $10 / 6$ containing both limonene and $\alpha$-pinene 
was $25 \%$, whereas the yield for the experiment $18 / 6$ with only $\alpha$-pinene was $32 \%$. In the mixed ABSOA experiment $11-12 / 6,14-15 / 6$ and $22 / 6$ the yields were between 18 and $30 \%$ depending on experimental conditions and aerosol loads. For the BSOA and ABSOA systems we achieved loss corrected $C_{\mathrm{OA}}$ in a range of $37-66 \mu \mathrm{g} \mathrm{m}^{-3}$, with the exception of experiment $22 / 6$ where the $C_{\mathrm{OA}}$ was $14.5 \mu_{\mathrm{g} \mathrm{m}}^{-3}$ (see Table 1). The potential synergetic effect on the BSOA yield are discussed further below but generally considering the variation of the experimental conditions we cannot detect a significant enhancement of the SOA yield by the presence of aromatic VOC.

\subsection{Mixed anthropogenic/biogenic secondary organic aerosols (ABSOA)}

Figure 3 shows the experiment ABSOA 22/6. Ozonolysis and reaction with $\mathrm{OH}$ radicals quickly convert the biogenic precursors $\alpha$-pinene and limonene while toluene is more slowly removed by $\mathrm{OH}$ producing a mixed aerosol (Fig. 3a). The aerosol is in the beginning dominated by biogenic SOA with slowly increasing anthropogenic contributions arising from the photo-oxidation of the aromatic precursors (total $\mathrm{OH}$ dose $5 \times 10^{10} \mathrm{~cm}^{-3} \mathrm{~s}$ ). The model estimated biogenic and anthropogenic contributions are shown as green and blue dashed lines (Fig. 3b). At the end of the experiment filter samples were collected and analysed for specific acids. In Fig. 3b (inset) results are shown from the filter analysis for a number of identified carboxylic acids and dimer esters. In Fig. $3 \mathrm{c}$ and $\mathrm{d}$ the corresponding properties of the aerosol as a function of time are shown.

AMS derived properties $f_{44}$, and $\mathrm{O} / \mathrm{C}$ are increasing with time (Fig. 3c) and $\mathrm{OH}$ dose (Fig. 3d). The $f_{43}$, which is a measure of the less oxidized compounds, is decreasing. The $f_{44}$ is closely related to $\mathrm{O} / \mathrm{C}$ but the $f_{44}$ is generally of higher quality (less noise) due to the higher sensitivity of the AMS measurements in the $\mathrm{V}$-mode, and consequently $f_{44}$ is replacing $\mathrm{O} / \mathrm{C}$ in parts of the evaluation. Figure $3 \mathrm{c}$ also includes a comparison between the ASOA fraction derived by the simple model and from measured $f_{44}$, see Sect. 3 , demonstrating the agreement between these two methods. (Note the down scaling of the model results by the factor of 1.4.)

Figure $3 \mathrm{~d}$ shows the volume fraction that remains in the condensed phase at a given temperature (VFR(343 K), $\operatorname{VFR}(373 \mathrm{~K})$, VFR(423 K), and $\operatorname{VFR}(463 \mathrm{~K})$ ) together with the $\mathrm{OH}$ dose and ASOA fraction. The behaviour of VFR was similar at all temperatures and VFR $(343 \mathrm{~K})$ will be used as an example in the following discussions. VFR continues to increase at all temperatures in the dark after the roof chamber is closed. This phenomenon was also observed in the other experiments, and indicates that non-photochemical processes must take place. Since $\mathrm{O} / \mathrm{C}, f_{44}$, and $f_{43}$ are levelling off when the roof is closed (duration $>6 \mathrm{~h}$ ), the processes may be even non-oxidative.

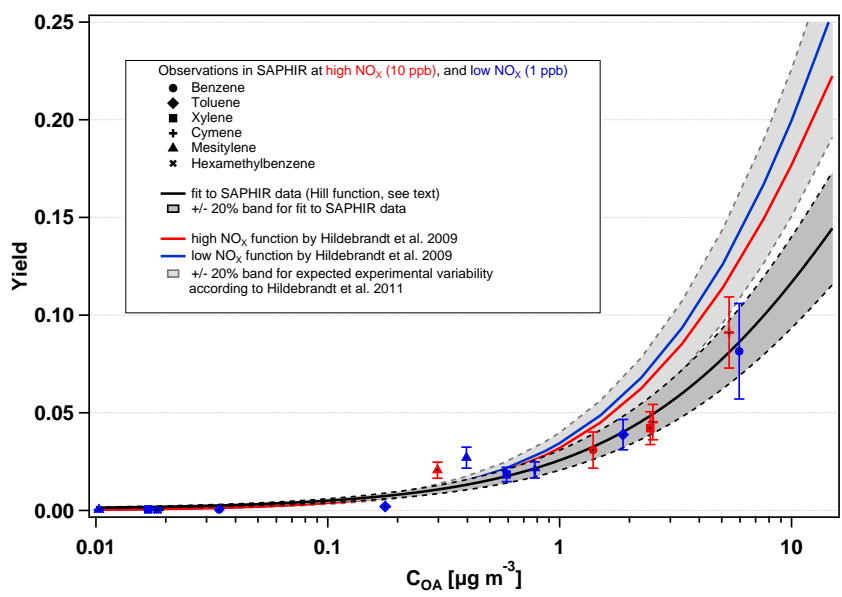

Fig. 2. ASOA mass yield as a function of the organic aerosol concentration for aromatic (anthropogenic) precursors and cymene. The data points and the black fitting curve were achieved in this study. The blue and red curves were calculated according to Hildebrandt et al. (2009). Bands of $\pm 20 \%$ uncertainty intervals are grey shaded. We acknowledge the kind support by Lea Hildebrandt.

Generally, the time behaviour of $f_{44}, f_{43}, \mathrm{O} / \mathrm{C}$ and volatility are in accordance with previous studies on SOA ageing (Tritscher et al., 2011; Salo et al., 2011). The complication in our experiments is that in addition to $\mathrm{OH}$ induced ageing and dark ageing of the SOA also the relative contribution of ASOA and BSOA is changing with time as can be seen in the ASOA fraction (blue line in Fig. 3b) with the final ASOA fraction estimated to about $56 \%$.

Table 2 provides the average of selected quantities at the end of the experiments, i.e. when the filters were taken. For ABSOA $22 / 6$ one can see that the reaction mixture was exposed to a relatively high $\mathrm{OH}$ dose $\left(5 \times 10^{10} \mathrm{~cm}^{-3} \mathrm{~s}\right)$ thus producing a less volatile (high VFR $(343 \mathrm{~K})$ ), aged aerosol with rather high $\mathrm{O} / \mathrm{C}$ ratio $(0.59 \pm 0.05)$ and a significant fraction of anthropogenic SOA (56\%). For the other ABSOA and BSOA experiments the $\mathrm{O} / \mathrm{C}$ ratios are lower.

For the pure ASOA 13/11 experiment the O/C ratio is high (0.79). It should be noted that in all ABSOA experiments except the 22/6, the AVOC and BVOC were added successively, which had implication on the final anthropogenic fraction. In Table 2 the $\mathrm{OH}$ dose is provided separately for the AVOC and BVOC taking into account when AVOC and BVOC, respectively, were added into the chamber. If for example comparing the ABSOA 11-12/6 with ABSOA 14-15/6 the BVOC are exposed to more $\mathrm{OH}$ in experiment $14-15 / 6$ providing increased $\operatorname{VFR}(343 \mathrm{~K})$ at somewhat higher $\mathrm{O} / \mathrm{C}$ ratio. Note that in exp. 11-12/6 the mixing fan broke during the first day. This affects the observed SOA mass as the lifetime of SOA in the SAPHIR chamber is longer with the fan switched off (Salo et al., 2011).

Since the properties of the aerosol at the time of filter sampling and the end of the experiment depend on several 

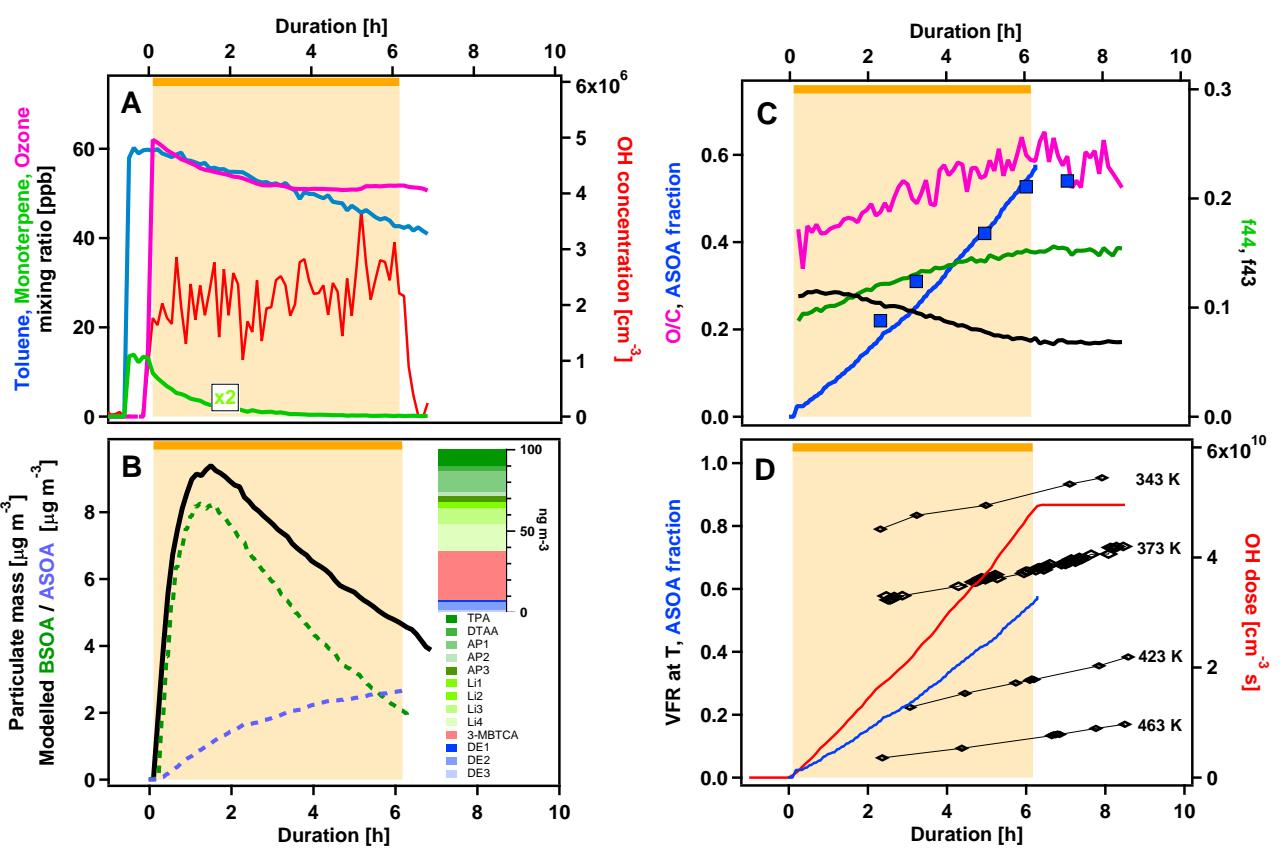

Fig. 3. ABSOA experiment 22/6 where biogenic and anthropogenic precursors are added simultaneously. (A) Concentrations of reactants toluene (blue), monoterpenes (green), ozone (magenta), $\mathrm{OH}$ (red). The variation of the $\mathrm{OH}$ signal is caused by variations in the actinic flux due to passing clouds. (B) Produced SOA (black), model derived biogenic (dashed green) and anthropogenic (dashed blue) SOA fractions. The inset shows the results of the filter analysis at the end of the experiment (compare Table 3). (C) O/C (magenta), $f_{44}$ (green), and $f_{43}$ (black), model derived ASOA fraction (blue line) and ASOA fraction derived from $f_{44}$ (blue squares). (D) Aerosol particle properties VFR(343 K), VFR(373 K), VFR(423 K), VFR(463 K) (black diamonds), together with the OH dose (red) and the model derived ASOA fraction (blue line).

aspects such as $\mathrm{OH}$ dose, reaction time and sequence of addition a more thorough analysis was necessary as described below. However, generally from the values provided in Table 2 one may conclude that increasing anthropogenic fraction and $\mathrm{OH}$ dose provided an aerosol with higher $\mathrm{O} / \mathrm{C}$ ratio and VFR(343 K).

\subsection{Speciation and compound classes in filter measurements}

Figure 4 shows total ion chromatograms of organic acids from the filter samples for two experiments, ASOA 11/6 and ABSOA 12/6. Exp. 11/6 shows fewer organic acids in ASOA from toluene compared to the number of organic acids in ABSOA, though it is important to note that the analytical method will primarily detect organic acids and not less polar molecules such as carbonyl compounds that could also contribute to SOA. The respective chromatogram of exp. 10/6 resembles that of exp. 11/6. SOA from photo-oxidation of toluene at high $\mathrm{NO}_{\mathrm{x}}$ conditions have been observed to consist of a high number of carbonyl compounds as well as small organic acids (Kleindienst et al., 2004), which may be difficult to detect using the applied analytical conditions.

Table 3 lists selected identified and quantified oxidation products of the precursors $\alpha$-pinene and limonene. Quantification of identified $\alpha$-pinene products showed strikingly

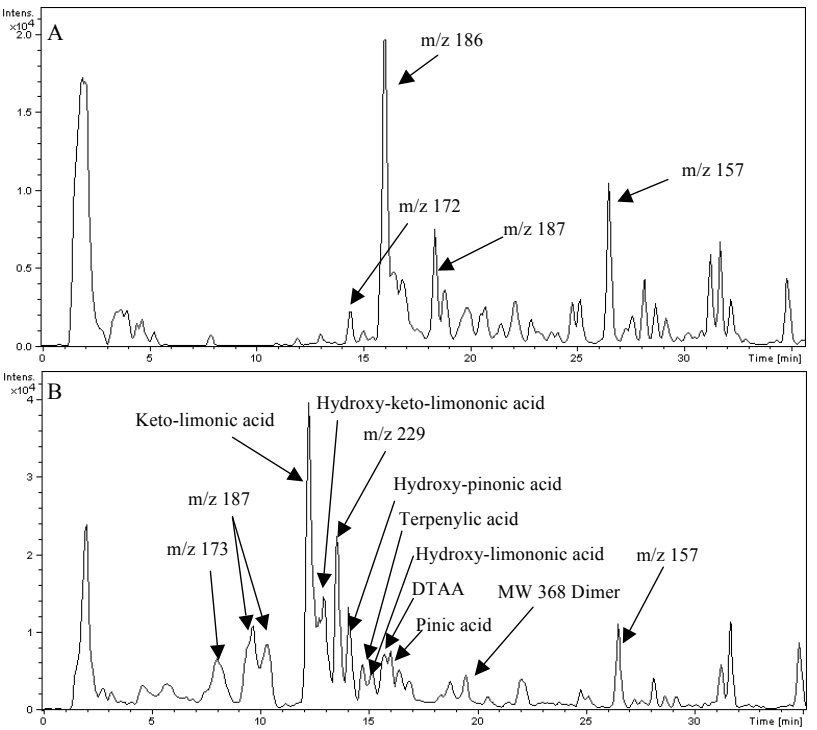

Fig. 4. Total ion chromatogram of organic acids in aerosols from (A) toluene after ageing (exp. 11/6), and (B) the same experiment after addition of BVOC mix and further ageing (exp. 12/6). Major identified and unidentified peaks are highlighted. 
Table 2. Summary of initial precursor concentrations and selected quantities at the time of filter collection. The OH dose is the accumulated measured dose since BVOC and AVOC addition, respectively. All uncertainties given are the statistical standard deviations.

\begin{tabular}{|c|c|c|c|c|c|c|c|c|}
\hline Experiment & $\begin{array}{l}\text { BVOC } \\
\text { precursor } \\
(\mathrm{ppb})\end{array}$ & $\begin{array}{l}\text { AVOC } \\
\text { precursor } \\
(\mathrm{ppb})\end{array}$ & $\begin{array}{l}\text { SOA mass } \\
\left(\mu \mathrm{g} \mathrm{m}^{-3}\right) \\
\pm \mathrm{stdev}\end{array}$ & $\begin{array}{l}\text { OH-dose } \\
\text { AVOC } \\
\left(\mathrm{cm}^{-3} \mathrm{~s}\right)\end{array}$ & $\begin{array}{l}\text { OH-dose } \\
\text { BVOC } \\
\left(\mathrm{cm}^{-3} \mathrm{~s}\right)\end{array}$ & $\begin{array}{l}\text { VFR } \\
(343 \mathrm{~K}) \\
\pm \text { stdev }\end{array}$ & $\begin{array}{l}\mathrm{O} / \mathrm{C} \\
\pm \mathrm{stdev}\end{array}$ & $\begin{array}{l}\text { ASOA } \\
\text { fraction }^{1} \\
(\%)\end{array}$ \\
\hline $\begin{array}{l}\text { ABSOA } \\
(11-12 / 6)\end{array}$ & $\begin{array}{l}\alpha \text {-pinene } \& \\
\text { limonene } \\
(40 \mathrm{ppb})\end{array}$ & $\begin{array}{l}\text { toluene } \\
\text { (85 ppb) }\end{array}$ & $14.6 \pm 0.6^{2}$ & $6.5 \times 10^{10}$ & $0.4 \times 10^{10}$ & $0.86 \pm 0.02$ & $0.43 \pm 0.02$ & $8(9)$ \\
\hline $\begin{array}{l}\text { ABSOA } \\
(14-15 / 6)\end{array}$ & $\begin{array}{l}\alpha \text {-pinene } \& \\
\text { limonene } \\
(40 \mathrm{ppb})\end{array}$ & $\begin{array}{l}\text { xylene } \\
(30 \mathrm{ppb})\end{array}$ & $5.7 \pm 0.4$ & $6.7 \times 10^{10}$ & $1.1 \times 10^{10}$ & $0.9 \pm 0.02$ & $0.45 \pm 0.03$ & $13(13)$ \\
\hline $\begin{array}{l}\text { ABSOA } \\
(22 / 6)\end{array}$ & $\begin{array}{l}\alpha \text {-pinene \& } \\
\text { limonene } \\
(8 \mathrm{ppb})\end{array}$ & $\begin{array}{l}\text { toluene } \\
(60 \mathrm{ppb})\end{array}$ & $3.5 \pm 0.4$ & $5.0 \times 10^{10}$ & $5.0 \times 10^{10}$ & $0.94 \pm 0.01$ & $0.59 \pm 0.05$ & $56(54)$ \\
\hline $\begin{array}{l}\text { ASOA } \\
(13 / 6)\end{array}$ & & $\begin{array}{l}\text { toluene } \\
\text { (85 ppb) }\end{array}$ & $4.7 \pm 0.4$ & $8.5 \times 10^{10}$ & $\mathrm{n} / \mathrm{a}$ & $0.98 \pm 0.01$ & $0.79 \pm 0.04$ & 100 \\
\hline $\begin{array}{l}\text { ASOA } \\
(14 / 6)\end{array}$ & & $\begin{array}{l}\text { xylene } \\
\text { (30 ppb) }\end{array}$ & $0.20 \pm 0.03$ & $5.6 \times 10^{10}$ & $\mathrm{n} / \mathrm{a}$ & $0.95 \pm 0.01$ & $0.44 \pm 0.22$ & 100 \\
\hline $\begin{array}{l}\mathrm{BSOA}^{3} \\
(18 / 6)\end{array}$ & $\begin{array}{l}\alpha \text {-pinene } \\
(40 \mathrm{ppb})\end{array}$ & & $26.2 \pm 1.6$ & $\mathrm{n} / \mathrm{a}$ & $2.1 \times 10^{10}$ & $0.79 \pm 0.01$ & $0.43 \pm 0.02$ & 0 \\
\hline $\begin{array}{l}\mathrm{BSOA}^{3,4} \\
(19 / 6)\end{array}$ & $\begin{array}{l}\alpha \text {-pinene } \\
(40 \mathrm{ppb})\end{array}$ & & $4.4 \pm 0.14$ & $\mathrm{n} / \mathrm{a}$ & $8.7 \times 10^{10}$ & $0.88 \pm 0.02$ & $0.46 \pm 0.03$ & 0 \\
\hline
\end{tabular}

${ }^{1}$ Values estimated from simple model, Sect. 3 , values in () from AMS measurements, Sect. $4.4{ }^{2}$ Longer SOA lifetime due to failure of mixing fan. ${ }^{3}$ Salo et al. (2011). ${ }^{4} 2 \mathrm{~h}$ after filter measurements.

similar concentrations (relative to total aerosol mass) within $15 \%$ in aerosol samples from experiments $10 / 6$ and $12 / 6$. This proves that there is a very good reproducibility of both the SAPHIR chamber experiments and chemical analysis. Exp. 10/6 and $12 / 6$ primarily differ in the order of introduction of VOC reactants to the SAPHIR chamber, where BVOC mix was added before toluene in exp. 10/6, while toluene was aged for $5.75 \mathrm{~h}$ before addition of BVOC mix in exp. 12/6. Since the concentrations of oxidation products from $\alpha$-pinene are quite similar in the two experiments, this indicates that the presence of toluene ASOA in the chamber prior to BVOC introduction does not significantly affect the composition of BSOA tracers for $\alpha$-pinene given in Table 3 .

The $\alpha$-pinene oxidation products can be grouped in firstgeneration products (a broadly defined group consisting of pinonic acid, cis-pinic acid, terpenylic acid and diaterpenylic acid acetate), an identified second-generation product MBTCA previously identified from gas-phase $\mathrm{OH}$ oxidation of pinonic acid (Müller et al., 2012) and suggested as tracer for pinene oxidation (Szmigielski et al., 2007) and dimer esters of $\alpha$-pinene oxidation products. The group of dimer esters covers the following specifically identified compounds: pinyl-diaterpenyl dimer ester (molecular weight, MW 358), pinonyl-pinyl dimer ester (MW 368) and terpenyldiaterpenyl dimer ester (MW 344) previously observed from ozonolysis of $\alpha$-pinene and $\beta$-pinene (Müller et al., 2008, 2009; Camredon et al., 2010; Yasmeen et al., 2010; Gao et al., 2010; Kristensen et al., 2012). The class concentration of the particulate organic matter are shown in Table 3 and presented in Fig. 5. In experiments 10/6 and 12/6, first generation $\alpha$-pinene oxidation products contribute about $3 \%$ to the aerosol mass, while the second generation product contributes only about $0.03 \%$. Dimer esters constitute about twice as much of the aerosol in exp. 10/6 compared to exp. $12 / 6(0.09 \%$ and $0.04 \%$ of the aerosol mass, respectively), which is probably due to the order of magnitude higher $\mathrm{OH}$ dose in exp. 10/6. In exp. 14-15/6 which differs from exp. $11 / 6-12 / 6$ in the use of xylene instead of toluene, only $40 \%$ of the aerosol mass was left when the filters were taken. The 
Table 3. Concentration of quantified BSOA tracer compounds in filter samples. All listed compounds were below detection limit in ASOA samples (11/6 and 13/6). Concentration in $\mathrm{ng} \mathrm{m}^{-3}$ if not stated elsewise. Molecular weights MW are given in $\mathrm{g} \mathrm{mol}^{-1}$. The detection limits were $1.1-3.5 \mathrm{ng} \mathrm{m}^{-3}$ and the error is estimated to $\pm 15 \%$.

\begin{tabular}{|c|c|c|c|c|c|c|}
\hline $\begin{array}{l}\text { Compound name, } \\
\text { abbreviation and MW }\end{array}$ & $\operatorname{ABSOA}(10 / 6)$ & ABSOA $(12 / 6)$ & $\operatorname{ABSOA}(15 / 6)$ & $\operatorname{ABSOA}(22 / 6)$ & $\operatorname{BSOA}(18 / 6)$ & $\operatorname{BSOA}(19 / 6)$ \\
\hline $\begin{array}{l}\text { Terpenylic acid } \\
\text { (TPA) } M W=172\end{array}$ & 28.7 & 28.6 & 11.1 & 10.9 & 76.6 & 11.6 \\
\hline $\begin{array}{l}\text { Diaterpenylic acid acetate } \\
\text { (DTAA)MW=232 }\end{array}$ & 6.9 & 3.7 & 2.0 & 2.8 & 25.3 & 5.2 \\
\hline $\begin{array}{l}\text { Pinic acid } \\
(\mathrm{AP} 1) \mathrm{MW}=186\end{array}$ & 63.9 & 69.2 & 17.2 & 12.7 & 613.5 & 36.3 \\
\hline $\begin{array}{l}\text { cis-pinonic acid } \\
(\mathrm{AP} 2) \mathrm{MW}=184\end{array}$ & 3.0 & 3.7 & 1.5 & 2.9 & 13.8 & 1.9 \\
\hline $\begin{array}{l}\text { Hydroxy-pinonic } \text { acid }^{2} \\
\text { (AP3) MW }=200\end{array}$ & 15.2 & 35.1 & 4.9 & 3.6 & 21.1 & 9.7 \\
\hline $\begin{array}{l}\text { Norlimonic acid } \\
\text { (Li1) } \mathrm{MW}=186\end{array}$ & 34.3 & 39.8 & 7.2 & 2.4 & & \\
\hline $\begin{array}{l}\text { Keto-limononic acid } \\
\text { (Li2) } \mathrm{MW}=186\end{array}$ & 7.9 & 19.5 & 11.8 & 1.3 & & \\
\hline $\begin{array}{l}\text { Keto-limonic acid } \\
\text { (Li3) } M W=188\end{array}$ & 188.7 & 158.1 & 20 & 9.4 & & \\
\hline $\begin{array}{l}\text { Hydroxy-keto-limononic acid }{ }^{1} \\
\text { (Li4) } M W=202\end{array}$ & 145.0 & 121.7 & 30.1 & 17.1 & & \\
\hline unknown acid $^{1} \mathrm{MW}=188$ & & & & & 97.2 & 9.8 \\
\hline unknown acid ${ }^{1} \mathrm{MW}=202$ & & & & & 111.6 & 13.5 \\
\hline $\begin{array}{l}\text { Sum of 1. generation products } \\
{\left[\mathrm{ng} \mathrm{m}^{-3} \text { air }\right]}\end{array}$ & 493.6 & 479.4 & 105.8 & 63.1 & 59.1 & 88 \\
\hline$\left[\mathrm{ng} \mu \mathrm{g}^{-1} \mathrm{PM}\right]$ & 30.1 & 32.8 & 18.6 & 18.0 & 36.6 & 13.8 \\
\hline $\begin{array}{l}\text { 2. generation product } \\
\text { 3-Methyl butane tricarboxylic } \\
\text { acid ( } 3 \text {-MBTCA) } M W=204 \\
{\left[\mathrm{ng} \mathrm{m}^{-3} \text { air }\right]}\end{array}$ & 4.1 & 4.4 & 4.8 & 30.2 & 320.8 & 42.7 \\
\hline$\left[\mathrm{ng} \mu \mathrm{g}^{-1} \mathrm{PM}\right]$ & 0.3 & 0.3 & 0.8 & 8.6 & 12.2 & 6.7 \\
\hline $\begin{array}{l}\text { Terpenyl-diaterpenyl dimer } \\
\text { ester }^{3} \text { (DE1) } \mathrm{MW}=344\end{array}$ & 0.7 & & & 0.7 & 18.3 & 1.8 \\
\hline $\begin{array}{l}\text { Pinyl-diaterpenyl dimer ester }{ }^{3} \\
\text { (DE2) } \mathrm{MW}=358\end{array}$ & 7.3 & 2.5 & 1.0 & 5.2 & 292.5 & 28.6 \\
\hline $\begin{array}{l}\text { Pinonyl-pinyl dimer ester }{ }^{2} \\
\text { (DE3) } \mathrm{MW}=368\end{array}$ & 7.4 & 3.5 & 1.4 & 1.4 & 141.8 & 11.5 \\
\hline $\begin{array}{l}\text { Sum dimer esters } \\
{\left[\mathrm{ng} \mathrm{m}^{-3} \text { air }\right]}\end{array}$ & 15.4 & 6 & 2.4 & 7.3 & 452.6 & 41.9 \\
\hline$\left[\mathrm{ng} \mu \mathrm{g}^{-1} \mathrm{PM}\right]$ & 0.9 & 0.4 & 0.4 & 2.1 & 17.3 & 6.5 \\
\hline
\end{tabular}

${ }^{1}$ Quantified using cis-pinic acid as surrogate standard. ${ }^{2}$ Quantified using cis-pinonic acid as surrogate standard. ${ }^{3}$ Quantified using averaged standard curves of the precursors (see Kristensen et al., 2012).

higher value in exp. 11-12/6 could be traced back to prolonged the SOA lifetime in the chamber.

In exp. 22/6 BVOC mix and toluene were added together to the SAPHIR chamber at the same time and the concentration of BVOC was about one fourth of the previous experiments. This is reflected in the total aerosol mass at the end of the experiment which was $3.5 \mathrm{\mu g} \mathrm{m}^{-3}$, about one fourth of exp. 10/6 and 12/6 (16.5 and $14.6 \mu \mathrm{g} \mathrm{m}^{-3}$, respectively). The lower BVOC concentration used in exp. 22/6 results in a generally lower concentration of almost all identified compounds compared to exp. 10/6 and 12/6 (Table 3). Interestingly, the second-generation oxidation product MBTCA however shows a significantly higher concentration in exp. 22/6 compared to exp. 10/6 and 12/6 constituting almost $1.4 \%$ of the total aerosol mass (Fig. 5). A possible explanation for the higher concentration of MBTCA in exp. 22/6 could be the higher OH-to-BVOC ratio compared to exp. $10 / 6$ and 12/6 which could increase the gas-phase oxidation and ageing of first-generation oxidation products such as cispinonic acid. Increased ageing in exp. 22/6 may also explain 


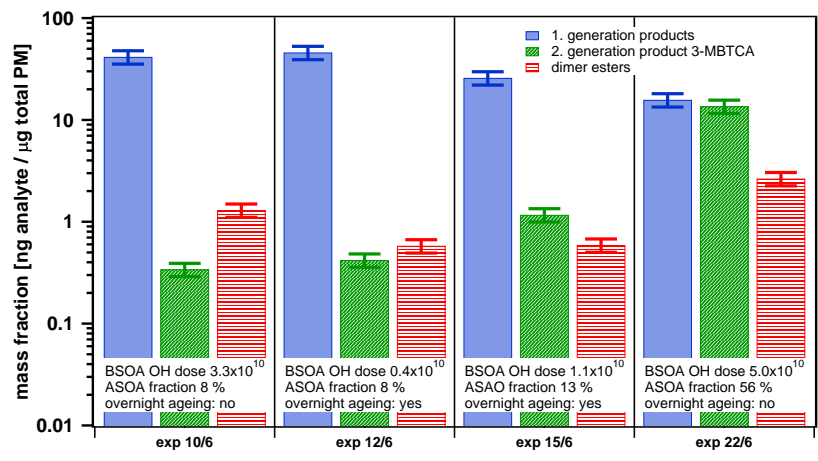

Fig. 5. Relative contribution of first generation products, second generation product 3-MBTCA, and dimer esters to the organic particulate mass. The $\mathrm{OH}$ dose seen by the BSOA fraction, the ASOA contribution and the long term ageing are denoted. Errors bars are $\pm 15 \%$.

the relatively high fraction of dimer esters $(0.33 \%$ of the aerosol mass) compared to exp. 10/6 and 12/6. This exp. 22/6 with the highest MBTCA fraction features also the largest $\mathrm{O} / \mathrm{C}$ and VFR(343 K) of all ABSOA experiments (Table 2).

\subsection{Volatility as function of time, $\mathrm{OH}$ dosis and degree of oxidation}

Figure 6 illustrates VFR( $343 \mathrm{~K})$ of five experiments where AVOC is represented by toluene or xylene, and BVOC is represented by equal amounts of $\alpha$-pinene and limonene. To disentangle the effects of photochemistry, processes in the dark and anthropogenic contribution, VFR $(343 \mathrm{~K})$ is displayed as function of experiment duration (upper panel), $\mathrm{OH}$ dose (middle panel) and $f_{44}$ (lower panel). In all panels the size of the markers corresponds to the model-estimated anthropogenic fraction of SOA.

In Fig. 6a the time evolution of $\operatorname{VFR}(343 \mathrm{~K})$ is shown as a function of elapsed time, where the starting time was defined by the start of particle formation induced either by opening the roof or by injection of AVOC into the illuminated chamber. The corresponding points in time of the VFR(343 K) measurements are indicated in Fig. 1. During the first 6 or $9 \mathrm{~h}$, respectively, when the reaction mixtures are exposed to sun light, the SOA become less volatile reflected as an increase of $\operatorname{VFR}(343 \mathrm{~K})$, no matter whether ASOA, ABSOA or BSOA was available. Figure 6a illustrate also that VFR(343 K) may increases with increasing anthropogenic contribution, with pure BSOA (18/6 and 10/6, first data point) and pure ASOA (11/6, 13/6 and 14/6) grouping at the bottom and the top of the VFR $(343 \mathrm{~K})$ scale, respectively. The ABSOA experiment 22/6 wherein AVOC and BVOC were mixed from the beginning is situated in between the pure systems.
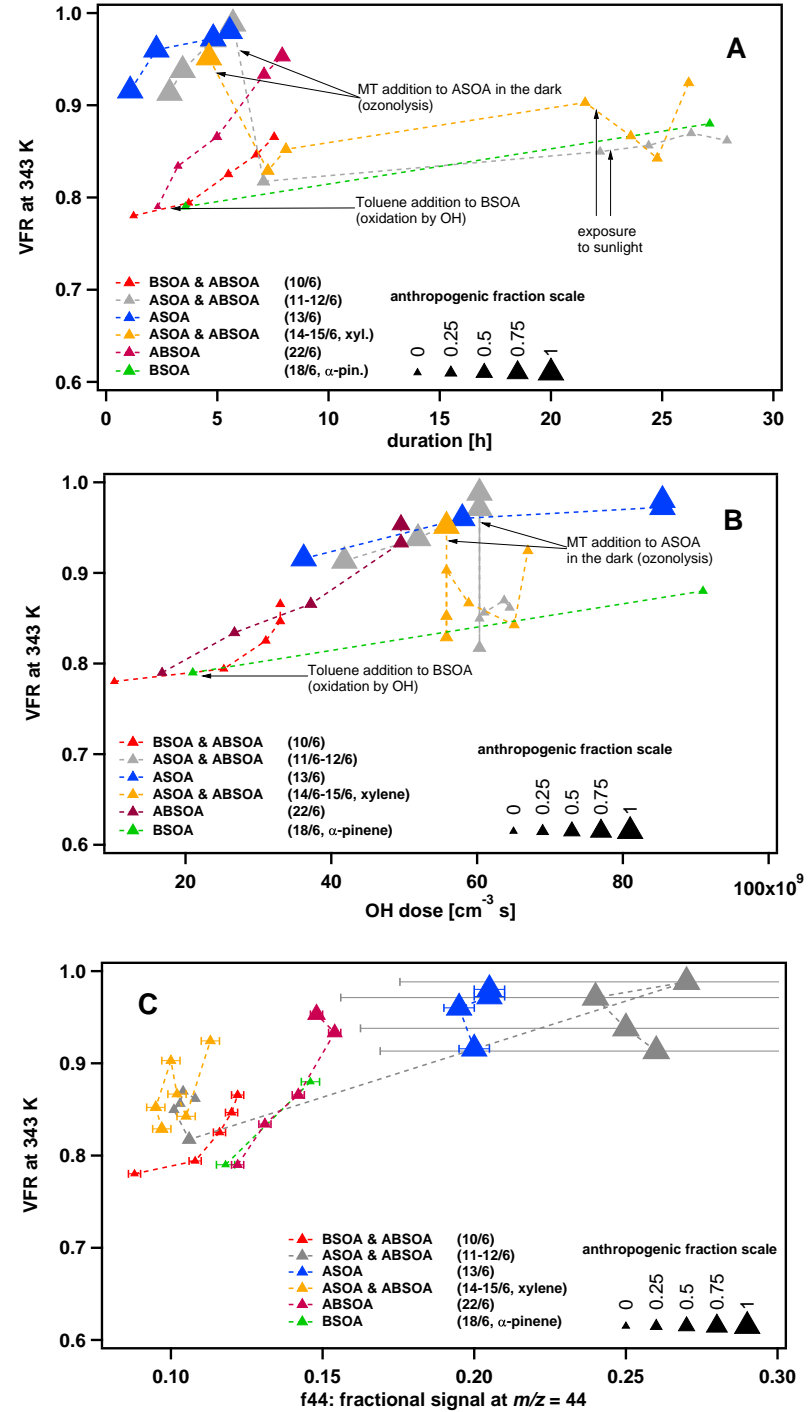

Fig. 6. VFR(343 K) for ABSOA experiments and BSOA experiment $18 / 6$ as a function of (A) elapsed time (B) OH dose (C) $f_{44} \cdot f_{44}$ for ASOA 11/26 have a large stdev (grey horizontal error bars) due to low signal compared to ASOA 13/6 (blue horizontal error bars).

In the two cases $11 / 6$ and $14 / 6$ when BVOC were added in the dark to pre-existing ASOA a significant drop in $\operatorname{VFR}(343 \mathrm{~K})$ is observed. The drop is due to condensation of fresh BSOA material arising from the ozonolysis of the BVOC. (Ozone was available from the previous photochemical processes.) The fresh BSOA component is leading to a much more volatile aerosol. However, the formed ABSOA is then getting less volatile during the night reflected as an increase of the VFR( $343 \mathrm{~K})$. In both cases the roof was opened the second day after about $23 \mathrm{~h}$. In the experiment 15/6 the photo-oxidation of BVOC and xylene formed fresh particulate material again generating more volatile aerosol. This is consistent with previous results (Salo et al., 2011) emphasising the importance of gas phase chemistry in the $\mathrm{OH}$ radical 
induced ageing of SOA. At the end of 15/6 the VFR(343 K) recovered and exceeds the value before light exposure, indicating that the ageing process continued after the production of fresh material had ceased, forming a less volatile SOA. The corresponding dip in $\operatorname{VFR}(343 \mathrm{~K})$ was not seen in the toluene case $12 / 6$ as the extra photo-oxidation did only add a small increase in SOA mass. The $\mathrm{OH}$ dose acting at the second day of experiment $15 / 6$ is about twice that of the exp. $12 / 6$ (see Fig. 6b) in accordance with production of more fresh material on $15 / 6$. It is noted that the filter analysis revealed more 2 nd generation product at the end of exp. 15/6 in accordance with the higher VFR(343 K) on this day.

Figure $6 \mathrm{~b}$ displays the VFR $(343 \mathrm{~K})$ as a function of the actual $\mathrm{OH}$ dose derived from the OH-LIF measurements. The lowest dose on the scale corresponds to $1.5 \mathrm{~h}$ exposure to average atmospheric $\mathrm{OH}$ levels of $2 \times 10^{6} \mathrm{~cm}^{-3}$, whereas the largest dose corresponds to $12 \mathrm{~h}$ exposure. For the aerosols in the dark, any change in the $\operatorname{VFR}(343 \mathrm{~K})$ falls on vertical lines at that $\mathrm{OH}$ dose seen by the pre-existing SOA. This $\mathrm{OH}$ dose has to be subtracted in order to get the actual $\mathrm{OH}$ dose acting on the added BSOA components during the photo-chemical ageing on the next day.

Presenting VFR(343 K) vs. the OH dose simplifies the picture for the first hours. Overall, the VFR of SOA increases with $\mathrm{OH}$ dose and the higher $\operatorname{VFR}(343 \mathrm{~K})$ for ASOA is partly caused by exposure to a larger $\mathrm{OH}$ dose. Experiment 15/6 and 22/6 show higher VFR(343 K) compared to exp. 10/6 and $12 / 6$, which were exposed to smaller $\mathrm{OH}$ dose. The latter have both lower 2 nd generation product fraction compared to $15 / 6$ and $22 / 6$, and smaller dimer fractions than exp. $22 / 6$ (Fig. 5). We conclude that the ageing and formation of a less volatile aerosol, reflected as an increase of VFR, is overall related to the $\mathrm{OH}$ dose, thus to photo-chemistry. The influence of the photo-chemistry on the BSOA components is also reflected in increasing 2 nd generation product and to less extent the dimer fraction.

For the pure ASOA the relative increase of $\operatorname{VFR}(343 \mathrm{~K})$ with $\mathrm{OH}$ dose is less pronounced, compared to ABSOA and BSOA dominated aerosols. The onset of ASOA particle formation and the first available VFR $(343 \mathrm{~K})$ data occur at larger $\mathrm{OH}$ dose, due to the lower reactivity of the AVOC. In addition first generation oxidation products of AVOC (mainly carbonyls see above) may have higher vapour pressures compared to the BVOC and more oxidation steps are needed to induce SOA formation. As a consequence the potential of ageing after particle formation is smaller for ASOA, since the vapours aged already in the gas-phase prior to particle formation. In contrast BSOA from the reactive precursors $\alpha$-pinene and limonene is formed already at low $\mathrm{OH}$ dose. In addition, during rapid formation, vapours with higher vapour pressures also reach saturation and contribute to the BSOA mass (Pankow, 1994; Odum et al., 1996), leading to a higher volatility early in the formation phase. These vapours will react (age) with $\mathrm{OH}$ and this leads to increasing low volatile second generation products e.g. MBTCA
(Müller et al., 2012). The curve for the mixed ABSOA (22/6) is connecting the BSOA experiment with the ASOA regime, as significant ASOA fraction is building up during the formation process (comp. Fig. 3b). Interestingly, for the exp. $10 / 6$ where toluene was added to pre-existing BSOA, the VFR $(343 \mathrm{~K})$ increase of the ABSOA with $\mathrm{OH}$ dose accelerates with increasing ASOA contribution. This behaviour is distinct although only up to $8-9 \%$ of the aerosol is calculated to be ASOA (Table 3). This suggests that even small contributions of ASOA can reduce the volatility and reduce the volatility of ABSOA. Moreover, the smallest change of $\operatorname{VFR}(343 \mathrm{~K})$ with $\mathrm{OH}$ dose is observed for the $\alpha$-pinene BSOA in experiment $18 / 6$, underlining an effect of the ASOA component for the mixed ABSOA.

After the roof was closed at the end of the day we took one data point in the dark with all other parameters unchanged. The VFR(343 K) continues to increase consistently for all investigated ASOA and ABSOA systems. One toluene experiment (13/6) was exposed to more $\mathrm{OH}$ than the others but still showed indications for ageing under dark conditions, however weaker. Since the volatility of ABSOA decreases also in the dark, the enhancement during daytime in experiment (10/6) may also have non-oxidative contributions (Kroll and Seinfeld, 2008; Kroll et al., 2011). Night time ageing processes were reported before by Tritscher et al. (2011) for $\alpha$-pinene SOA.

Figure $6 \mathrm{c}$ shows the $\operatorname{VFR}(343 \mathrm{~K})$ as function of $f_{44}$, which is related to the $\mathrm{O} / \mathrm{C}$ ratio for biogenic and aromatic systems (Aiken et al., 2008; Chhabra et al., 2010, 2011). Simplistically, a higher $f_{44}$ indicates increasing contribution of carboxylic acids. Here we deploy less data points since the detection level was insufficient for the xylene ASOA.

The two pure ASOA systems show high VFR(343 K), and the largest $f_{44}$ signal at 0.2 and $\sim 0.25$, respectively. The $f_{44}$ are larger than $f_{44}$ reported by Chhabra et al. (2011) $(0.05-0.1)$ and in the range of $f_{44}$ reported by Aiken et al. (2008) for ambient urban aerosol. For the ASOA in exp. $11 / 6$ the standard deviation of $f_{44}$ is large (0.09) while in exp. $13 / 6$ it is significantly lower (0.004). A difference between these two experiments is that in the $13 / 6$ a small addition of $\mathrm{NO}_{\mathrm{x}}$ was made but from the yield curve shown in Fig. 2 this should not influence the aerosol production. Considering the large scatter of the $f_{44}$ data on the $11 / 6$ we neglect this data for the further considerations and assume that pure ASOA systems have $f_{44}$ of 0.2 in line with the $13 / 6$ experiments. Independent of that, the large observed $f_{44}$ for pure ASOA corroborates our suggestion that more oxidation steps are needed and that AVOC vapours are more oxidized before they form particulate matter, probably because they have smaller C-backbones.

The fresh mixed ABSOA 22/6 features low $\operatorname{VFR}(343 \mathrm{~K})$ of 0.79 at $f_{44}$ of 0.11 . During on-going photo-oxidation $\operatorname{VFR}(343 \mathrm{~K})$ is increasing with increasing $f_{44}$. At $f_{44}$ of 0.15 the VFR $(343 \mathrm{~K})$ of the ABSOA reaches values in between the pure BSOA with $f_{44} \approx 0.1$ and the pure ASOA 
systems with $f_{44} \sim 0.2$. An increase of $f_{44}$ is also seen in exp. 10/6 after toluene was added to the BSOA aerosol. The increase of VFR $(343 \mathrm{~K})$ with $f_{44}$ in experiment $10 / 6$ is similar to $22 / 6$, but shifted to $20 \%$ lower $f_{44}$ values. The change in $\operatorname{VFR}(343 \mathrm{~K})$ with $f_{44}$ for both ABSOA experiments is stronger than that for $\alpha$-pinene BSOA, which in addition has been exposed to a much larger $\mathrm{OH}$ dose. The steep increase of VFR $(343 \mathrm{~K})$ for the ABSOA systems with $f_{44}$ supports that the presence of ASOA components reduces the volatility of the aerosols, possibly in a non-stoichiometric fashion. The strong tendency to increase VFR with only small changes in oxidation state would be commensurable with oligomerisation processes, which were first described for trimethylbenzene, also an aromatic precursor (Kalberer et al., 2004).

The addition of BVOC to ASOA followed by ozonolysis in exp. 11/6 and 14/6 reduces $f_{44}$ from about 0.2 to about 0.1 in both cases, i.e. the aerosol is obviously dominated by BSOA. In the ABSOA exp. 12/6 not much change occurred when exposing the ABSOA to sunlight the second day while in the ABSOA 15/6 chemical changes during the dip in $\operatorname{VFR}(343 \mathrm{~K})$ were observed with $f_{44}$ increasing with sun exposure and $\mathrm{OH}$ dose from 0.10 to 0.11 .

In summary, ASOA shows larger VFR(343 K), i.e. lower volatility associated to higher degree of oxidation than BSOA and ABSOA. To reach the larger degree of oxidation longer exposure to $\mathrm{OH}$ radicals is needed. In ABSOA already small fractions of ASOA lead to strong increase in VFR( $343 \mathrm{~K})$, even at low degrees of oxidation, indicating that ASOA components trigger a reduced volatility either by oligomerisation or morphological changes e.g. formation of glassy states (Zobrist et al., 2008; Virtanen et al., 2010). Since VFR(343 K) increase also overnight in presence of low ozone concentrations, a slow non-photochemical, if not non-oxidative ageing process must also take place. This process is not much affecting the oxidation state and could be oligomerization by condensation reactions (Kroll and Seinfeld, 2008; Kroll et al., 2011).

\subsection{Anthropogenic enhancement}

Using the combination of data from pure and mixed systems the question regarding anthropogenic enhancement can be addressed. As described above there is potential for enhancements both regarding the yield and VFR. The evidence on more than an additive effect is crucial depending on the estimate of the anthropogenic fraction. Using the anthropogenic fraction derived from the simple model, one can compare linear combinations of the properties from the pure systems with measured quantities at the end of the mixed experiment. The most direct case is the experiment 22/6, where the SOA precursors were added simultaneously and the ASOA fraction is estimated to $56 \%$ by the model. The linear mixing of $f_{44}$ asoa and $f_{44}$ bsoa according to Eqs. (1) and (2) enabled us to corroborate the model predicted ASOA fraction, see Table 2. A complication in applying linear mixing is to have comparable $\mathrm{OH}$ dose and the total aerosol loading (see Table 2). For O/C ratios as described above a linear combination for experiment $18-19 / 6 \mathrm{BSOA}(\mathrm{O} / \mathrm{C}=0.46$ at $\mathrm{OH}$ dose $=8.7 \times 10^{10} \mathrm{~cm}^{-3} \mathrm{~s}$ ) and for experiment 13/6 ASOA $\left(\mathrm{O} / \mathrm{C}=0.79\right.$ at $\mathrm{OH}$ dose $\left.=8.5 \times 10^{10} \mathrm{~cm}^{-3} \mathrm{~s}\right)$ is able to describe the measured $\mathrm{O} / \mathrm{C}\left(0.59\right.$ at dose $\left.=5.0 \times 10^{10} \mathrm{~cm}^{-3} \mathrm{~s}\right)$ at the end of experiment 22/6. This implies that there is not much room for non-linear mixing effects on $\mathrm{O} / \mathrm{C}$ (and $f_{44}$ ) of the ABSOA if the estimated anthropogenic fraction is $56 \%$ in experiment $22 / 6$. The yield comparison is slightly more complex since the yields have larger uncertainly. Again looking into experiment $22 / 6$, the calculated yield at the end of the experiment was $18 \%$. The yield from the experiment with limonene and $\alpha$-pinene (10/6) has a yield of $25 \%$ while the ASOA yield estimates from Eq. (4) at an aerosol load of $3.5 \mu \mathrm{g} \mathrm{m}^{-3}$ is $11 \%$. The linear combination of those using $55 \%$ ASOA fraction is about $19 \%$. This is surprisingly close to the yield observed, and in line with no anthropogenic enhancement.

Compared to other properties the volatility responded differently to the mixing. In Fig. 7 we show VFR(343 K) as function of the ASOA fraction, as predicted by the model. The data is colored by experiment day as in Fig. 6. For clarity we omitted two intermediate data points on the second day for experiment $11 / 6$ and 14/6. The lower bound of the shaded area connects VFR(343 K) for the fresh pure BSOA (experiment 18/6) with that for fresh pure ASOA (experiment 13/6). The $\mathrm{OH}$ dose for these two data points was low $2.1 \times 10^{10}$ and $3.6 \times 10^{10}$, respectively, but not exactly the same. As stated above, a higher $\mathrm{OH}$ dose is needed before ASOA is formed. The upper bound of the shaded area is given by $\operatorname{VFR}(343 \mathrm{~K})$ achieved at the highest $\mathrm{OH}$ dose of $\approx 9 \times 10^{10} \mathrm{~cm}^{-3} \mathrm{~s}$ for both BSOA (experiment 19/6) and ASOA (experiment 13/6).

As can be seen in Fig. 7 overall the VFR(343 K) increases with increasing ASOA fraction. In addition photochemical processes and processes in the dark are affecting VFR(343 K). The effect of OH-dose, i.e. increasing exposure to photochemical processing, can be followed by increasing size of the circles. This is clearly shown for the pure systems at ASOA fraction $=0$ and ASOA fraction $=1$, where VFR increases with the $\mathrm{OH}$ dose. One may note that for experiments with high fraction of BSOA there is also a slight increase in VFR that happens in the dark. For experiments 11/6 and 14/6 this effect was discussed in detail in Sect. 4.4.

With the focus on ASOA fraction and $\mathrm{OH}$ dose as key parameters, one can clearly observe an enhancing effect of ASOA components on VFR(343 K). Herein we understand enhancement as something that is more prominent than the linear mixing effect due to the ASOA fraction considering also the effect of $\mathrm{OH}$ dose. Three clear cases of an enhancement effect were observed: 
1. Experiment 10/6 shows a strong increase of $\operatorname{VFR}(343 \mathrm{~K})$ after toluene was added to the reactive system. A high VFR $(343 \mathrm{~K})$ of 0.85 is reached although the $\mathrm{OH}$ dose was low compared to BSOA in experiment 18/6.

2. In experiment $22 / 6$ the mixed ABSOA reached an VFR(343 K) of 0.93 - typical for pure ASOA - with only $56 \%$ ASOA fraction and at an $40 \%$ lower OH dose than the high $\mathrm{OH}$ dose boundary of $9 \times 10^{10} \mathrm{~cm}^{-3} \mathrm{~s}$.

3. The photochemical processed ABSOA on the second day in experiments $11-12 / 6$ and 14-15/6 reach high VFR at ASOA fractions of less than 10 and $15 \%$, respectively, and exposure to a low $\mathrm{OH}$ dose on second day. This effect is more pronounced for experiment 14/6 with somewhat larger OH dose and slightly larger ASOA fraction.

In summary, the $\mathrm{O} / \mathrm{C}$ (and $f_{44}$ ) as well as the SOA yield in the mixed experiment $22 / 6$ can be explained by a simple linear mixing of the pure ASOA and BSOA components, while the VFR is clearly enhanced by ASOA over-proportional to the mass fraction. This conclusion is based on the ASOA fraction derived from the model. Therefore it is important to note that the model has been constrained with the $f_{44}$ measurements. $\mathrm{O} / \mathrm{C}$ and $f_{44}$ are unlikely to be affected in a non-linear way. Thus, if the model significantly overestimates the ASOA fraction, this will implicate synergetic effects to low $\mathrm{O} / \mathrm{C}$, low $f_{44}$ and low SOA yield while the VFR can be described by a linear combination. If the opposite is valid, i.e. the model is overestimating the ASOA fraction the VFR enhancement effect would be even stronger than outlined above.

\section{Atmospheric implications}

Oxidation of aromatics and other traditional anthropogenic VOCs can contribute significantly to SOA formation. Using newly derived aerosol yields de Gouw et al. (2008) accounted for a large fraction $(37 \%)$ by oxidation of traditional anthropogenic SOA precursors and the remaining fraction remained unexplained. A large unexplained fraction was typical for model and measurements comparisons and has been addressed in several previous studies where e.g. Volkamer et al. (2006) specifically demonstrated how ASOA was under-predicted in urban air masses by up to a factor of 10. During recent years several explanations have been suggested for these inconsistencies. One finding is that SOA formation from aromatic systems has significant higher yields than previously reported which was further recognised in our study (Table 1 and Fig. 2). However, in the study of de Gouw et al. (2008) the higher yields from aromatic system were already applied and $63 \%$ SOA mass was still found unexplained. Other explanations for this gap

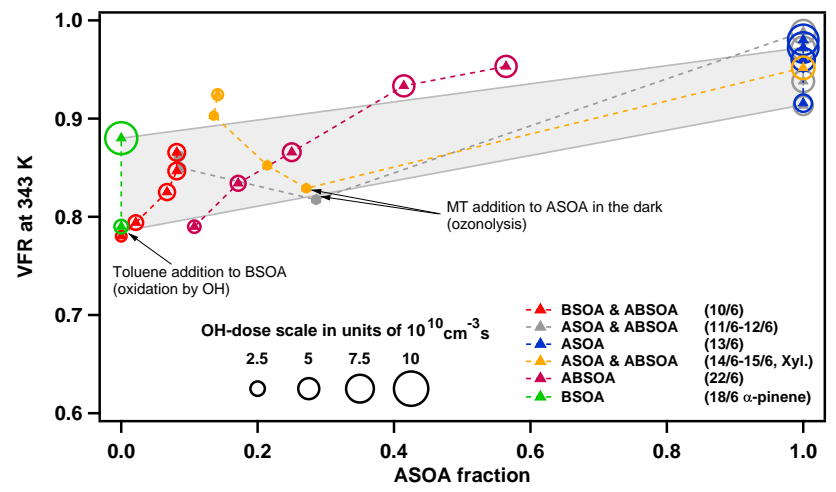

Fig. 7. VFR(343 K) for ABSOA experiments and BSOA experiment $18 / 6$ (triangles) as a function of the model derived ASOA fraction with $\mathrm{OH}$ dose indicate by the size of the circles. The lower boundary of the shaded area is given by $\operatorname{VFR}(343 \mathrm{~K})$ for freshly formed aerosol at $\mathrm{OH}$ doses of $\approx 1-2 \times 10^{10} \mathrm{~cm}^{-3}$ s for pure BSOA and of $3.6 \times 10^{10} \mathrm{~cm}^{-3} \mathrm{~s}$ for pure ASOA. The upper boundary line connects pure BSOA (18/6) and pure ASOA (13/6) at about the same $\mathrm{OH}$ dose $\approx 9 \times 10^{10} \mathrm{~cm}^{-3} \mathrm{~s}$. Enhancement due to ASOA components is evident when $\operatorname{VFR}(343 \mathrm{~K})$ is large at small ASOA fraction, and/or small $\mathrm{OH}$ dose at the same time: 10/6 (increase of $\operatorname{VFR}(343 \mathrm{~K})$ at small ASOA fraction), 22/6 (very high VFR(343 K) at $50 \%$ ASOA fraction), 11/6 and 14/6 (high $\operatorname{VFR}(343 \mathrm{~K}$ ) at small ASOA fraction and very low $\mathrm{OH}$ dose).

can be missing primary precursors, oxidation of intermediate volatile compounds and effective ageing of SOA (Pye and Seinfeld, 2010). All these issues have been addressed in a series of modelling studies of air pollution in Mexico as part of the MILAGRO experiment (see e.g. Tsimpidi et al., 2011; Dzepina et al., 2009, 2011; Hodzic et al., 2010). The finding from the present study that mixed ASOA and BSOA can evolve rapidly producing an aerosol with low volatility favours an ageing treatment in models with reduced evaporation upon dilution with increasing $\mathrm{OH}$ exposure (Dzepina et al., 2011).

Using a combination of global modelling efforts and observations of organic aerosol mass (AMS) and organic carbon (filters) Spracklen et al. (2011) proposed a new source attribution of SOA. According to their analysis $2 / 3$ of the SOA may have biogenic precursors but is strongly related with the $\mathrm{CO}$ source distribution, an anthropogenic tracer. Such effects were proposed before by de Gouw et al. (2005, 2008) and de Gouw and Jimenez (2009). This portion of SOA is called anthropogenic enhanced SOA. Our findings of an over-proportional enhancement effect of ASOA components on volatility may contribute to understand anthropogenic enhancement. Aromatic emissions are surely closely related to $\mathrm{CO}$ emissions and if an ASOA fraction of $10 \%$ or more is available this should decrease the volatility of the resulting ABSOA. The volatility reduction is not available in remote, biogenically dominated regions, where aromatic emissions are absent. Since ABSOA is less volatile than BSOA, less BSOA is observed than ABSOA at same source strength of 
BVOC. However we also showed that $\mathrm{OH}$ dose is an important driver of ageing of SOA and is affecting its volatility, thus we do not claim that we can fully explain the anthropogenic enhancement. However such effects of aromatics could contribute significantly to anthropogenic enhancement.

The exposure of the reaction mixtures to natural $\mathrm{OH}$ dose and the long duration of experiments lead to concentrations of monoterpene oxidation products as listed in Table 3, that are generally higher, but still comparable to concentrations found in aerosol samples from ambient air (Kristensen and Glasius, 2011; Zhang et al., 2010). Dimer esters have previously been identified from ozonolysis of $\alpha$-pinene in smog chamber studies and ambient air (e.g. Camredon et al., 2010; Kristensen et al., 2012). Our results can be connected to atmospheric conditions using the $\mathrm{OH}$ dose, for example the $\mathrm{OH}$ dose in BSOA $22 / 6$ is $5.0 \times 10^{10} \mathrm{~cm}^{-3} \mathrm{~s}$ and corresponds to $7 \mathrm{~h}$ of exposure to an $\mathrm{OH}$ radical concentration of $2 \times 10^{6} \mathrm{~cm}^{-3} \mathrm{~s}$. The final aerosol mass of $3.5 \mu \mathrm{g} \mathrm{m}^{-3}$ is also comparable to atmospheric observations of organic aerosol mass in urban plumes (Tsimpidi et al., 2011). We thus conclude that our findings are transferable to the atmosphere.

\section{Conclusions}

The main focus of this work was to study aerosol formation and properties from photo-oxidation of mixed aromatic and monoterpene precursors (as examples of anthropogenic and biogenic VOC) to mimic real world conditions. In a separate set of experiments also the aerosol yields of SOA were quantified. The aromatic yield data were used to estimate the ASOA contribution to aerosol mass in the mixed ABSOA experiments applying a simplified model. The estimated ASOA contributions ranged from very small $(>1 \%)$ up to significant fraction ( $>50 \%$ ), providing a suitable range to study the effect of ASOA on aerosol properties. Absolute measurements of $\mathrm{OH}$ radicals were used to constrain the estimated conversion of aromatic precursor in the mixed experiments and providing a direct measure on $\mathrm{OH}$ dose.

The volatility of the aerosol is an important measure of the thermal persistence of particles in the atmosphere, and was used in combination with the $\mathrm{OH}$ dose, anthropogenic fraction and chemical composition of the particles to understand the underlying aerosol processes. Aromatic anthropogenic systems produced aerosol with lower volatility than the biogenic monoterpene system. However, in order to produce significant anthropogenic aerosol fraction the systems were exposed to large $\mathrm{OH}$ doses, corresponding to oxidation over several hours at mid-European photochemical conditions. The larger $\mathrm{OH}$ dose did also influence the chemical composition as evidenced by higher concentrations of dimer esters and second generation products in the particles. The VFR(343 K) generally increased with increasing $\mathrm{OH}$ dose, but if a reactive VOC was added or a system with remaining gas phase vapour was exposed again to sunlight the VFR $(343 \mathrm{~K})$ dropped temporarily in analogy to the observation described in Salo et al. (2011). Since the ASOA had a lower volatility than BSOA any changes in the anthropogenic fraction did influence the overall volatility. Furthermore, it was demonstrated that this effect was more than additive, i.e. presence of ASOA induced decreased volatility (increased VFR) that could not be explained by a linear combination of volatility properties of ASOA and BSOA. This was in contrast to other properties such as $f_{44}$ and $\mathrm{O} / \mathrm{C}$ as well as the overall SOA yield that within experimental uncertainties could be described by a linear combination of the pure systems.

In addition to $\mathrm{OH}$ induced ageing and the anthropogenic fraction of the particles, the VFR $(343 \mathrm{~K})$ was also affected by a time dependent ageing, that occurred during dark hours, and might be linked to condensed phase processes such as polymerisation. The observed volatility changes and associated processes were compared to the chemical composition of the aerosol, O/C and $f_{44}$. Analogous to the $\operatorname{VFR}(343 \mathrm{~K})$ changes, the $\mathrm{O} / \mathrm{C}$ ratio increased due to $\mathrm{OH}$ induced ageing and with increasing anthropogenic fraction. However, for the third process, that dominated VFR $(343 \mathrm{~K})$ changes during dark hours, no relation to $\mathrm{O} / \mathrm{C}$ ratio could be established. The interpretation is that this process does not change the overall chemical composition but the volatility, and was consequently attributed to changes in viscosity, e.g. induced by polymerisation.

Given the observation in the particulate phase and the exposure to natural sun-light at realistic $\mathrm{OH}$ concentrations our findings should be applicable to the atmosphere. The reduced volatility induced by ASOA (and OH dose) have an influence on the atmospheric SOA lifetime, where the BSOA fraction in mixed ABSOA should have longer lifetimes and thus higher abundance in anthropogenically influenced areas with distinct aromatic emissions compared to BSOA in natural regions. This effect may contribute to the so-called anthropogenic enhancement and should be considered in regional and global model predictions.

Acknowledgements. This project was supported by EUROCHAMP-2 (Integration of European Simulation Chambers for Investigating Atmospheric Processes) - EC 7th framework, Swedish Formas (214-2010-1756), the Swedish Research Council (80475101) and the Tellus research platform at University of Gothenburg. The research presented is a contribution to the Swedish strategic research area ModElling the Regional and Global Earth system, MERGE. We would like to thank M. Fenger (Aarhus University) for help with chemical analysis of filter samples. Sascha Nehr thanks the Deutsche Forschungsgemeinschaft for support under grant BO 1580/3-1. We cordially thank Lea Hildebrandt for providing us her data for comparisons. Finally, we would like to thank the two anonymous reviewers for encouraging us to clearer work out the enhancement effect. 
The service charges for this open access publication

have been covered by a Research Centre of the

Helmholtz Association.

Edited by: F. Keutsch

\section{References}

Aiken, A. C., DeCarlo, P. F., and Jimenez, J. L.: Elemental analysis of organic species with electron ionization highresolution mass spectrometry, Anal. Chem., 79, 8350-8358, doi:10.1021/ac071150w, 2007.

Aiken, A. C., DeCarlo, P. F., Kroll, J. H., Worsnop, D. R., Huffman, J. A., Docherty, K. S., Ulbrich, I. M., Mohr, C., Kimmel, J. R., Sueper, D., Sun, Y., Zhang, Q., Trimborn, A., Northway, M., Ziemann, P. J., Canagaratna, M. R., Onasch, T. B., Alfarra, M. R., Prevot, A. S. H., Dommen, J., Duplissy, J., Metzger, A., Baltensperger, U., and Jimenez, J. L.: O/C and OM/OC ratios of primary, secondary, and ambient organic aerosols with highresolution time-of-flight aerosol mass spectrometry, Environ. Sci. Technol., 42, 4478-4485, doi:10.1021/es703009q, 2008.

Aiken, A. C., Salcedo, D., Cubison, M. J., Huffman, J. A., DeCarlo, P. F., Ulbrich, I. M., Docherty, K. S., Sueper, D., Kimmel, J. R., Worsnop, D. R., Trimborn, A., Northway, M., Stone, E. A., Schauer, J. J., Volkamer, R. M., Fortner, E., de Foy, B., Wang, J., Laskin, A., Shutthanandan, V., Zheng, J., Zhang, R., Gaffney, J., Marley, N. A., Paredes-Miranda, G., Arnott, W. P., Molina, L. T., Sosa, G., and Jimenez, J. L.: Mexico City aerosol analysis during MILAGRO using high resolution aerosol mass spectrometry at the urban supersite (T0) - Part 1: Fine particle composition and organic source apportionment, Atmos. Chem. Phys., 9, 6633-6653, doi:10.5194/acp-9-6633-2009, 2009.

Allan, J. D., Delia, A. E., Coe, H., Bower, K. N., Alfarra, M. R., Jimenez, J. L., Middlebrook, A. M., Drewnick, F., Onasch, T. B., Canagaratna, M. R., Jayne, J. T., and Worsnop, D. R.: A generalised method for the extraction of chemically resolved mass spectra from aerodyne aerosol mass spectrometer data, J. Aerosol Sci., 35, 909-922, doi:10.1016/j.jaerosci.2004.02.007, 2004.

Berndt, T. and Böge, O.: Rate constants for the gas-phase reaction of hexamethylbenzene with $\mathrm{OH}$ radicals and $\mathrm{H}$ atoms and of 1,3,5-trimethylbenzene with $\mathrm{H}$ atoms, International Journal of Chemical Kinetics, 33, 124-129, 10.1002/10974601(200102)33:2;124::aid-kin1004¡3.0.co;2-s, 2001.

Bohn, B., Rohrer, F., Brauers, T., and Wahner, A.: Actinometric measurements of $\mathrm{NO}_{2}$ photolysis frequencies in the atmosphere simulation chamber SAPHIR, Atmos. Chem. Phys., 5, 493-503, doi:10.5194/acp-5-493-2005, 2005.

Camredon, M., Hamilton, J. F., Alam, M. S., Wyche, K. P., Carr, T., White, I. R., Monks, P. S., Rickard, A. R., and Bloss, W. J.: Distribution of gaseous and particulate organic composition during dark $\alpha$-pinene ozonolysis, Atmos. Chem. Phys., 10, 2893-2917, doi:10.5194/acp-10-2893-2010, 2010.

Carlton, A. G., Pinder, R. W., Bhave, P. V., and Pouliot, G. A.: To What Extent Can Biogenic SOA be Controlled?, Environ. Sci. Technol., 44, 3376-3380, doi:10.1021/es903506b, 2010.

Chhabra, P. S., Flagan, R. C., and Seinfeld, J. H.: Elemental analysis of chamber organic aerosol using an aerodyne high-resolution aerosol mass spectrometer, Atmos. Chem. Phys., 10, 4111-4131, doi:10.5194/acp-10-4111-2010, 2010.
Chhabra, P. S., Ng, N. L., Canagaratna, M. R., Corrigan, A. L., Russell, L. M., Worsnop, D. R., Flagan, R. C., and Seinfeld, J. H.: Elemental composition and oxidation of chamber organic aerosol, Atmos. Chem. Phys., 11, 8827-8845, doi:10.5194/acp-11-88272011, 2011.

de Gouw, J. A. and Jimenez, J. L.: Organic Aerosols in the Earth's Atmosphere, Environ. Sci. Technol., 43, 7614-7618, doi:10.1021/es9006004, 2009.

de Gouw, J. A., Middlebrook, A. M., Warneke, C., Goldan, P. D., Kuster, W. C., Roberts, J. M., Fehsenfeld, F. C., Worsnop, D. R., Canagaratna, M. R., Pszenny, A. A. P., Keene, W. C., Marchewka, M., Bertman, S. B., and Bates, T. S.: Budget of organic carbon in a polluted atmosphere: Results from the New England Air Quality Study in 2002, J. Geophys. Res.-Atmos., 110, D16305, doi:10.1029/2004jd005623, 2005.

de Gouw, J. A., Brock, C. A., Atlas, E. L., Bates, T. S., Fehsenfeld, F. C., Goldan, P. D., Holloway, J. S., Kuster, W. C., Lerner, B. M., Matthew, B. M., Middlebrook, A. M., Onasch, T. B., Peltier, R. E., Quinn, P. K., Senff, C. J., Stohl, A., Sullivan, A. P., Trainer, M., Warneke, C., Weber, R. J., and Williams, E. J.: Sources of particulate matter in the northeastern United States in summer: 1. Direct emissions and secondary formation of organic matter in urban plumes, J. Geophys. Res.-Atmos., 113, D08301, doi:10.1029/2007jd009243, 2008.

DeCarlo, P. F., Kimmel, J. R., Trimborn, A., Northway, M. J., Jayne, J. T., Aiken, A. C., Gonin, M., Fuhrer, K., Horvath, T., Docherty, K. S., Worsnop, D. R., and Jimenez, J. L.: Field-deployable, high-resolution, time-of-flight aerosol mass spectrometer, Anal. Chem., 78, 8281-8289, doi:10.1021/ac061249n, 2006.

Derwent, R. G., Jenkin, M. E., Utembe, S. R., Shallcross, D. E., Murrells, T. P., and Passant, N. R.: Secondary organic aerosol formation from a large number of reactive manmade organic compounds, Sci. Total Environ., 408, 3374-3381, doi:10.1016/j.scitotenv.2010.04.013, 2010.

Dzepina, K., Volkamer, R. M., Madronich, S., Tulet, P., Ulbrich, I. M., Zhang, Q., Cappa, C. D., Ziemann, P. J., and Jimenez, J. L.: Evaluation of recently-proposed secondary organic aerosol models for a case study in Mexico City, Atmos. Chem. Phys., 9, 5681-5709, doi:10.5194/acp-9-5681-2009, 2009.

Dzepina, K., Cappa, C. D., Volkamer, R. M., Madronich, S., DeCarlo, P. F., Zaveri, R. A., and Jimenez, J. L.: Modeling the Multiday Evolution and Aging of Secondary Organic Aerosol During MILAGRO 2006, Environ. Sci. Technol., 45, 3496-3503, doi:10.1021/es103186f, 2011.

Fuchs, H., Dorn, H.-P., Bachner, M., Bohn, B., Brauers, T., Gomm, S., Hofzumahaus, A., Holland, F., Nehr, S., Rohrer, F., Tillmann, R., and Wahner, A.: Comparison of $\mathrm{OH}$ concentration measurements by DOAS and LIF during SAPHIR chamber experiments at high $\mathrm{OH}$ reactivity and low NO concentration, Atmos. Meas. Tech., 5, 1611-1626, doi:10.5194/amt-5-1611-2012, 2012.

Fushimi, A., Wagai, R., Uchida, M., Hasegawa, S., Takahashi, K., Kondo, M., Hirabayashi, M., Morino, Y., Shibata, Y., Ohara, T., Kobayashi, S., and Tanabe, K.: Radiocarbon ((14)C) Diurnal Variations in Fine Particles at Sites Downwind from Tokyo, Japan in Summer, Environ. Sci. Technol., 45, 6784-6792, doi:10.1021/es201400p, 2011.

Galloway, M. M., Loza, C. L., Chhabra, P. S., Chan, A. W. H., Yee, L. D., Seinfeld, J. H., and Keutsch, F. N.: Analysis of photochemical and dark glyoxal uptake: Implications for SOA formation, 
Geophys. Res. Lett., 38, L17811, doi:10.1029/2011g1048514, 2011.

Gao, Y. Q., Hall, W. A., and Johnston, M. V.: Molecular Composition of Monoterpene Secondary Organic Aerosol at Low Mass Loading, Environ. Sci. Technol., 44, 7897-7902, doi:10.1021/es101861k, 2010.

Glasius, M., la Cour, A., and Lohse, C.: Fossil and nonfossil carbon in fine particulate matter: A study of five European cities, J. Geophys. Res.-Atmos., 116, D11302, doi:10.1029/2011jd015646, 2011.

Goldstein, A. H. and Galbally, I. E.: Known and unexplored organic constituents in the Earth's atmosphere, Environ. Sci. Technol., 41, 1514-1521, 2007.

Hallquist, M., Wenger, J. C., Baltensperger, U., Rudich, Y., Simpson, D., Claeys, M., Dommen, J., Donahue, N. M., George, C., Goldstein, A. H., Hamilton, J. F., Herrmann, H., Hoffmann, T., Iinuma, Y., Jang, M., Jenkin, M. E., Jimenez, J. L., Kiendler-Scharr, A., Maenhaut, W., McFiggans, G., Mentel, Th. F., Monod, A., Prévôt, A. S. H., Seinfeld, J. H., Surratt, J. D., Szmigielski, R., and Wildt, J.: The formation, properties and impact of secondary organic aerosol: current and emerging issues, Atmos. Chem. Phys., 9, 5155-5236, doi:10.5194/acp-9-51552009, 2009.

Heald, C. L., Kroll, J. H., Jimenez, J. L., Docherty, K. S., DeCarlo, P. F., Aiken, A. C., Chen, Q., Martin, S. T., Farmer, D. K., and Artaxo, P.: A simplified description of the evolution of organic aerosol composition in the atmosphere, Geophys. Res. Lett., 37, L08803, doi:10.1029/2010g1042737, 2010.

Healy, R. M., Temime, B., Kuprovskyte, K., and Wenger, J. C.: Effect of Relative Humidity on Gas/Particle Partitioning and Aerosol Mass Yield in the Photooxidation of p-Xylene, Environ. Sci. Technol., 43, 1884-1889, doi:10.1021/es802404z, 2009.

Hildebrandt, L., Donahue, N. M., and Pandis, S. N.: High formation of secondary organic aerosol from the photo-oxidation of toluene, Atmos. Chem. Phys., 9, 2973-2986, doi:10.5194/acp-92973-2009, 2009.

Hildebrandt, L., Henry, K. M., Kroll, J. H., Worsnop, D. R., Pandis, S. N., and Donahue, N. M.: Evaluating the Mixing of Organic Aerosol Components Using High-Resolution Aerosol Mass Spectrometry, Environ. Sci. Technol., 45, 6329-6335, doi:10.1021/es200825g, 2011.

Hodzic, A., Jimenez, J. L., Madronich, S., Canagaratna, M. R., DeCarlo, P. F., Kleinman, L., and Fast, J.: Modeling organic aerosols in a megacity: potential contribution of semi-volatile and intermediate volatility primary organic compounds to secondary organic aerosol formation, Atmos. Chem. Phys., 10, 5491-5514, doi:10.5194/acp-10-5491-2010, 2010.

Hoyle, C. R., Boy, M., Donahue, N. M., Fry, J. L., Glasius, M., Guenther, A., Hallar, A. G., Huff Hartz, K., Petters, M. D., Petäjä, T., Rosenoern, T., and Sullivan, A. P.: A review of the anthropogenic influence on biogenic secondary organic aerosol, Atmos. Chem. Phys., 11, 321-343, doi:10.5194/acp-11-321-2011, 2011.

Hu, D., Bian, Q., Li, T. W. Y., Lau, A. K. H., and Yu, J. Z.: Contributions of isoprene, monoterpenes, beta-caryophyllene, and toluene to secondary organic aerosols in Hong Kong during the summer of 2006, J. Geophys. Res.-Atmos., 113, D22206, doi:10.1029/2008jd010437, 2008.

Hurley, M. D., Sokolov, O., Wallington, T. J., Takekawa, H., Karasawa, M., Klotz, B., Barnes, I., and Becker, K. H.: Organic aerosol formation during the atmospheric degradation of toluene, Environ. Sci. Technol., 35, 1358-1366, doi:10.1021/es0013733, 2001.

Izumi, K. and Fukuyama, T.: Photochemical aerosol formation from aromatic-hydrocarbons in the presence of $\mathrm{NO}_{\mathrm{x}}$, Atmos. Environ. a-Gen, 24, 1433-1441, doi:10.1016/0960-1686(90)90052-o, 1990.

Jaoui, M., Edney, E. O., Kleindienst, T. E., Lewandowski, M., Offenberg, J. H., Surratt, J. D., and Seinfeld, J. H.: Formation of secondary organic aerosol from irradiated alphapinene/toluene/ $\mathrm{NO}(\mathrm{x})$ mixtures and the effect of isoprene and sulfur dioxide, J. Geophys. Res.-Atmos., 113, D09303, doi:10.1029/2007jd009426, 2008.

Jimenez, J. L., Canagaratna, M. R., Donahue, N. M., Prevot, A. S. H., Zhang, Q., Kroll, J. H., DeCarlo, P. F., Allan, J. D., Coe, H., Ng, N. L., Aiken, A. C., Docherty, K. S., Ulbrich, I. M., Grieshop, A. P., Robinson, A. L., Duplissy, J., Smith, J. D., Wilson, K. R., Lanz, V. A., Hueglin, C., Sun, Y. L., Tian, J., Laaksonen, A., Raatikainen, T., Rautiainen, J., Vaattovaara, P., Ehn, M., Kulmala, M., Tomlinson, J. M., Collins, D. R., Cubison, M. J., Dunlea, E. J., Huffman, J. A., Onasch, T. B., Alfarra, M. R., Williams, P. I., Bower, K., Kondo, Y., Schneider, J., Drewnick, F., Borrmann, S., Weimer, S., Demerjian, K., Salcedo, D., Cottrell, L., Griffin, R., Takami, A., Miyoshi, T., Hatakeyama, S., Shimono, A., Sun, J. Y., Zhang, Y. M., Dzepina, K., Kimmel, J. R., Sueper, D., Jayne, J. T., Herndon, S. C., Trimborn, A. M., Williams, L. R., Wood, E. C., Middlebrook, A. M., Kolb, C. E., Baltensperger, U., and Worsnop, D. R.: Evolution of Organic Aerosols in the Atmosphere, Science, 326, 1525-1529, doi:10.1126/science.1180353, 2009.

Jonsson, Å. M., Hallquist, M., and Saathoff, H.: Volatility of secondary organic aerosols from the ozone initiated oxidation of [alpha]-pinene and limonene, J. Aerosol Sci., 38, 843-852, 2007.

Jordan, A., Haidacher, S., Hanel, G., Hartungen, E., Mark, L., Seehauser, H., Schottkowsky, R., Sulzer, P., and Mark, T. D.: A high resolution and high sensitivity proton-transfer-reaction time-offlight mass spectrometer (PTR-TOF-MS), International J. Mass Spectrom., 286, 122-128, doi:10.1016/j.ijms.2009.07.005, 2009.

Kalberer, M., Paulsen, D., Sax, M., Steinbacher, M., Dommen, J., Prevot, A. S. H., Fisseha, R., Weingartner, E., Frankevich, V., Zenobi, R., and Baltensperger, U.: Identification of polymers as major components of atmospheric organic aerosols, Science, 303, 1659-1662, doi:10.1126/science.1092185, 2004.

Kanakidou, M., Seinfeld, J. H., Pandis, S. N., Barnes, I., Dentener, F. J., Facchini, M. C., Van Dingenen, R., Ervens, B., Nenes, A., Nielsen, C. J., Swietlicki, E., Putaud, J. P., Balkanski, Y., Fuzzi, S., Horth, J., Moortgat, G. K., Winterhalter, R., Myhre, C. E. L., Tsigaridis, K., Vignati, E., Stephanou, E. G., and Wilson, J.: Organic aerosol and global climate modelling: a review, Atmos. Chem. Phys., 5, 1053-1123, doi:10.5194/acp-5-1053-2005, 2005.

Kautzman, K. E., Surratt, J. D., Chan, M. N., Chan, A. W. H., Hersey, S. P., Chhabra, P. S., Dalleska, N. F., Wennberg, P. O., Flagan, R. C., and Seinfeld, J. H.: Chemical Composition of Gas- and Aerosol-Phase Products from the Photooxidation of Naphthalene, J. Phys. Chem. A, 114, 913-934, doi:10.1021/jp908530s, 2010.

Kleindienst, T. E., Conver, T. S., McIver, C. D., and Edney, E. O.: Determination of secondary organic aerosol prod- 
ucts from the photooxidation of toluene and their implications in ambient PM2.5, J. Atmos. Chem., 47, 79-100, doi:10.1023/b:joch.0000012305.94498.28, 2004.

Kristensen, K. and Glasius, M.: Organosulfates and oxidation products from biogenic hydrocarbons in fine aerosols from a forest in North West Europe during spring, Atmos. Environ., 45, 45464556, doi:10.1016/j.atmosenv.2011.05.063, 2011.

Kristensen, K., Enggrob, K. L., King, S. M., Worton, D. R., Platt, S. M., Mortensen, R., Rosenoern, T., Surratt, J. D., Bilde, M., Goldstein, A. H., and Glasius, M.: Formation and occurrence of dimer esters of pinene oxidation products in atmospheric aerosols, Atmos. Chem. Phys. Discuss., 12, 2210322137, doi:10.5194/acpd-12-22103-2012, 2012.

Kroll, J. H. and Seinfeld, J. H.: Chemistry of secondary organic aerosol: Formation and evolution of low-volatility organics in the atmosphere, Atmos. Environ., 42, 3593-3624, 2008.

Kroll, J. H., Donahue, N. M., Jimenez, J. L., Kessler, S. H., Canagaratna, M. R., Wilson, K. R., Altieri, K. E., Mazzoleni, L. R., Wozniak, A. S., Bluhm, H., Mysak, E. R., Smith, J. D., Kolb, C. E., and Worsnop, D. R.: Carbon oxidation state as a metric for describing the chemistry of atmospheric organic aerosol, Nature Chemistry, 3, 133-139, doi:10.1038/nchem.948, 2011

Lambe, A. T., Onasch, T. B., Massoli, P., Croasdale, D. R., Wright, J. P., Ahern, A. T., Williams, L. R., Worsnop, D. R., Brune, W. H., and Davidovits, P.: Laboratory studies of the chemical composition and cloud condensation nuclei $(\mathrm{CCN})$ activity of secondary organic aerosol (SOA) and oxidized primary organic aerosol (OPOA), Atmos. Chem. Phys., 11, 8913-8928, doi:10.5194/acp11-8913-2011, 2011.

Müller, L., Reinnig, M.-C., Warnke, J., and Hoffmann, Th.: Unambiguous identification of esters as oligomers in secondary organic aerosol formed from cyclohexene and cyclohexene/apinene ozonolysis, Atmos. Chem. Phys., 8, 1423-1433, doi:10.5194/acp-8-1423-2008, 2008.

Müller, L., Reinnig, M. C., Hayen, H., and Hoffmann, T.: Characterization of oligomeric compounds in secondary organic aerosol using liquid chromatography coupled to electrospray ionization Fourier transform ion cyclotron resonance mass spectrometry, Rapid Communications in Mass Spectrometry, 23, 971-979, doi:10.1002/rcm.3957, 2009.

Müller, L., Reinnig, M.-C., Naumann, K. H., Saathoff, H., Mentel, T. F., Donahue, N. M., and Hoffmann, T.: Formation of 3-methyl1,2,3-butanetricarboxylic acid via gas phase oxidation of pinonic acid - a mass spectrometric study of SOA aging, Atmos. Chem. Phys., 12, 1483-1496, doi:10.5194/acp-12-1483-2012, 2012.

Ng, N. L., Kroll, J. H., Chan, A. W. H., Chhabra, P. S., Flagan, R. C., and Seinfeld, J. H.: Secondary organic aerosol formation from $m$-xylene, toluene, and benzene, Atmos. Chem. Phys., 7, 3909-3922, doi:10.5194/acp-7-3909-2007, 2007.

Odum, J. R., Hoffmann, T., Bowman, F., Collins, D., Flagan, R. C., and Seinfeld, J. H.: Gas/particle partitioning and secondary organic aerosol yields, Environ. Sci. Technol., 30, 2580-2585, doi:10.1021/es950943+, 1996.

Pankow, J. F.: An absorption model of gas/particle partitioning of organic compounds in the atmosphere, Atmos. Environ., 28, 185-188, 1994.

Pye, H. O. T. and Seinfeld, J. H.: A global perspective on aerosol from low-volatility organic compounds, Atmos. Chem. Phys., 10, 4377-4401, doi:10.5194/acp-10-4377-2010, 2010.
Rohrer, F., Bohn, B., Brauers, T., Brüning, D., Johnen, F.-J., Wahner, A., and Kleffmann, J.: Characterisation of the photolytic HONO-source in the atmosphere simulation chamber SAPHIR, Atmos. Chem. Phys., 5, 2189-2201, doi:10.5194/acp-5-21892005, 2005.

Salo, K., Hallquist, M., Jonsson, Å. M., Saathoff, H., Naumann, K.H., Spindler, C., Tillmann, R., Fuchs, H., Bohn, B., Rubach, F., Mentel, Th. F., Müller, L., Reinnig, M., Hoffmann, T., and Donahue, N. M.: Volatility of secondary organic aerosol during $\mathrm{OH}$ radical induced ageing, Atmos. Chem. Phys., 11, 11055-11067, doi:10.5194/acp-11-11055-2011, 2011.

Shantz, N. C., Aklilu, Y. A., Ivanis, N., Leaitch, W. R., Brickell, P. C., Brook, J. R., Cheng, Y., Halpin, D., Li, S. M., Tham, Y. A., Toom-Sauntry, D., Prenni, A. J., and Graham, L.: Chemical and physical observations of particulate matter at Golden Ears Provincial Park from anthropogenic and biogenic sources, Atmos. Environ., 38, 5849-5860, doi:10.1016/j.atmosenv.2004.01.050, 2004.

Sato, K., Hatakeyama, S., and Imamura, T.: Secondary organic aerosol formation during the photooxidation of toluene: NOx dependence of chemical composition, J. Phys. Chem. A, 111, 9796-9808, doi:10.1021/jp071419f, 2007.

Song, C., Na, K., Warren, B., Malloy, Q., and Cocker, D. R.: Secondary organic aerosol formation from the photooxidation of p- and o-xylene, Environ. Sci. Technol., 41, 7403-7408, doi:10.1021/es0621041, 2007.

Spracklen, D. V., Jimenez, J. L., Carslaw, K. S., Worsnop, D. R., Evans, M. J., Mann, G. W., Zhang, Q., Canagaratna, M. R., Allan, J., Coe, H., McFiggans, G., Rap, A., and Forster, P.: Aerosol mass spectrometer constraint on the global secondary organic aerosol budget, Atmos. Chem. Phys., 11, 12109-12136, doi:10.5194/acp-11-12109-2011, 2011.

Steinbrecher, R., Klauer, M., Hauff, K., Stockwell, W. R., Jaeschke, W., Dietrich, T., and Herbert, F.: Biogenic and anthropogenic fluxes of non-methane hydrocarbons over an urban-impacted forest, Frankfurter Stadtwald, Germany, Atmos. Environ., 34, 37793788, doi:10.1016/s1352-2310(99)00518-x, 2000.

Szidat, S., Jenk, T. M., Synal, H. A., Kalberer, M., Wacker, L., Hajdas, I., Kasper-Giebl, A., and Baltensperger, U.: Contributions of fossil fuel, biomass-burning, and biogenic emissions to carbonaceous aerosols in Zurich as traced by C-14, J. Geophys. Res.Atmos., 111, D07206, doi:10.1029/2005jd006590, 2006.

Szidat, S., Ruff, M., Perron, N., Wacker, L., Synal, H.-A., Hallquist, M., Shannigrahi, A. S., Yttri, K. E., Dye, C., and Simpson, D.: Fossil and non-fossil sources of organic carbon (OC) and elemental carbon (EC) in Göteborg, Sweden, Atmos. Chem. Phys., 9, 1521-1535, doi:10.5194/acp-9-1521-2009, 2009.

Szmigielski, R., Surratt, J. D., Gomez-Gonzalez, Y., Van der Veken, P., Kourtchev, I., Vermeylen, R., Blockhuys, F., Jaoui, M., Kleindienst, T. E., Lewandowski, M., Offenberg, J. H., Edney, E. O., Seinfeld, J. H., Maenhaut, W., and Claeys, M.: 3-methyl1,2,3-butanetricarboxylic acid: An atmospheric tracer for terpene secondary organic aerosol, Geophys. Res. Lett., 34, L24811, doi:10.1029/2007g1031338, 2007.

Takekawa, H., Minoura, H., and Yamazaki, S.: Temperature dependence of secondary organic aerosol formation by photooxidation of hydrocarbons, Atmos. Environ., 37, 3413-3424, doi:10.1016/s1352-2310(03)00359-5, 2003. 
Tritscher, T., Dommen, J., DeCarlo, P. F., Gysel, M., Barmet, P. B., Praplan, A. P., Weingartner, E., Prévôt, A. S. H., Riipinen, I., Donahue, N. M., and Baltensperger, U.: Volatility and hygroscopicity of aging secondary organic aerosol in a smog chamber, Atmos. Chem. Phys., 11, 11477-11496, doi:10.5194/acp11-11477-2011, 2011.

Tsimpidi, A. P., Karydis, V. A., Zavala, M., Lei, W., Bei, N., Molina, L., and Pandis, S. N.: Sources and production of organic aerosol in Mexico City: insights from the combination of a chemical transport model (PMCAMx-2008) and measurements during MILAGRO, Atmos. Chem. Phys., 11, 5153-5168, doi:10.5194/acp11-5153-2011, 2011.

Virtanen, A., Joutsensaari, J., Koop, T., Kannosto, J., Yli-Pirila, P., Leskinen, J., Makela, J. M., Holopainen, J. K., Pöschl, U., Kulmala, M., Worsnop, D. R., and Laaksonen, A.: An amorphous solid state of biogenic secondary organic aerosol particles, Nature, 467, 824-827, doi:10.1038/nature09455, 2010.

Volkamer, R., Jimenez, J. L., San Martini, F., Dzepina, K., Zhang, Q., Salcedo, D., Molina, L. T., Worsnop, D. R., and Molina, M. J.: Secondary organic aerosol formation from anthropogenic air pollution: Rapid and higher than expected, Geophys. Res. Lett., 33, L17811, doi:10.1029/2006g1026899, 2006.
Yasmeen, F., Vermeylen, R., Szmigielski, R., Iinuma, Y., Böge, O., Herrmann, H., Maenhaut, W., and Claeys, M.: Terpenylic acid and related compounds: precursors for dimers in secondary organic aerosol from the ozonolysis of $\alpha$ - and $\beta$-pinene, Atmos. Chem. Phys., 10, 9383-9392, doi:10.5194/acp-10-9383-2010, 2010.

Zhang, Y. Y., Müller, L., Winterhalter, R., Moortgat, G. K., Hoffmann, T., and Pöschl, U.: Seasonal cycle and temperature dependence of pinene oxidation products, dicarboxylic acids and nitrophenols in fine and coarse air particulate matter, Atmos. Chem. Phys., 10, 7859-7873, doi:10.5194/acp-10-7859-2010, 2010.

Zobrist, B., Marcolli, C., Pedernera, D. A., and Koop, T.: Do atmospheric aerosols form glasses?, Atmos. Chem. Phys., 8, 52215244, doi:10.5194/acp-8-5221-2008, 2008. 